
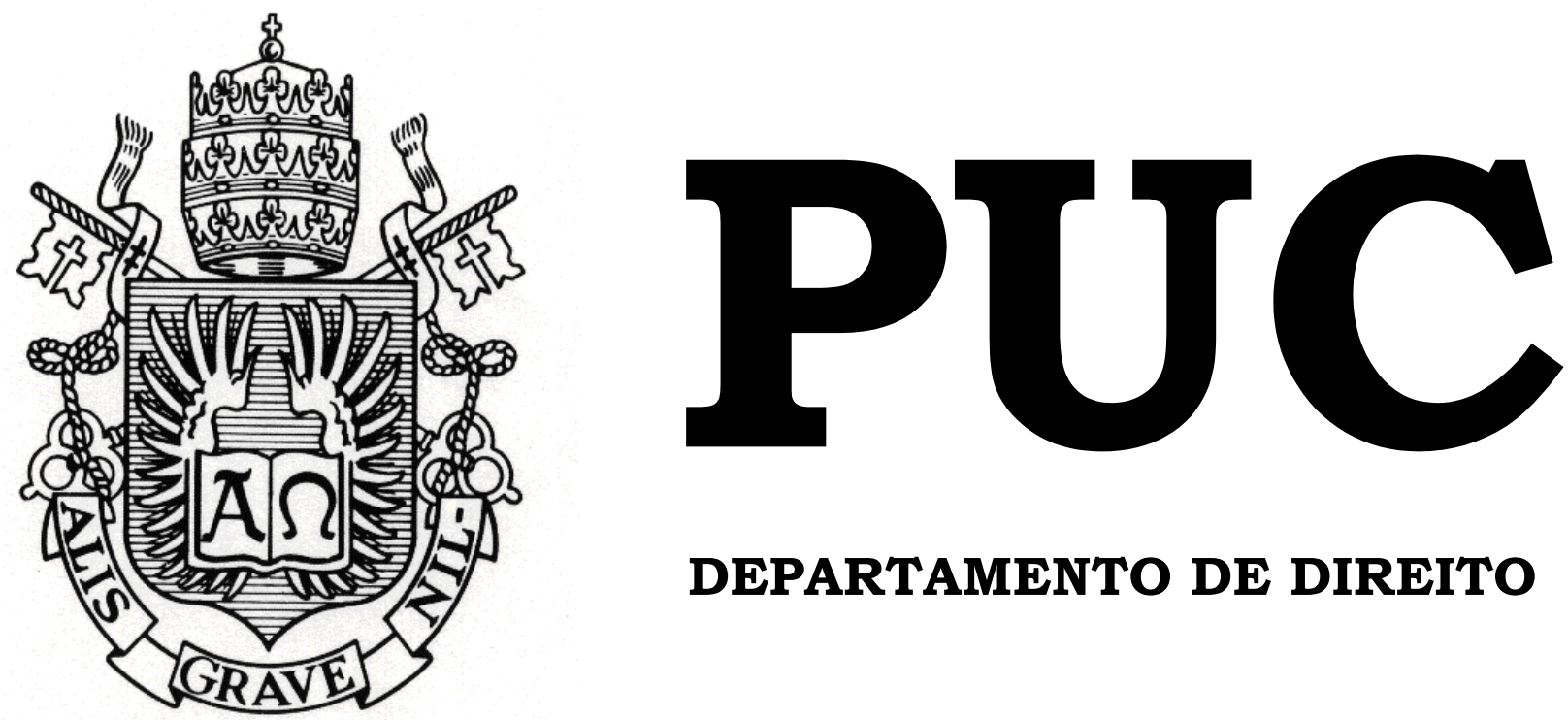

DEPARTAMENTO DE DIREITO

\title{
O Resseguro no Brasil
}

por

Vivian Tristão Rios

orientador:

GUILHERME VALDETARO

2005.1

PONTIFÍCIA UNIVERSIDADE CATÓLICA DO RIO DE JANEIRO

RUA MARQUÊS DE SÃO VICENTE, 225 - CEP 22451-900

RIO DE JANEIRO - BRASIL 


\title{
O Resseguro no Brasil
}

\author{
por
}

\section{Vivan Tristão Rios}

Monografia apresentada ao

Departamento de Direito da Pontifícia Universidade Católica do Rio de Janeiro (PUC-Rio) para a obtenção do Título de Bacharel em Direito.

Orientador: Guilherme Valdetaro 


\section{Resumo}

O presente trabalho se propõe a abordar o instituto do resseguro, tendo como foco a peculiaridade monopolista do mercado brasileiro e sua perspectiva de abertura.

Para adequada compreensão do assunto, inicia-se o estudo pelos seus elementos fundamentais, o seguro e o risco. Em seguida, conceitua-se o resseguro, sendo ressaltada sua função primordial de pulverização de riscos, bem como, as outras formas de pulverização de riscos, o co-seguro, a retrocessão e os pools ressecuritários. Adiante, aborda-se os aspectos históricos e a evolução da atividade resseguradora no mundo e no Brasil. No capítulo subseqüente, destaca-se a importância das funções específicas do resseguro, a mercadológica, gerencial, financeira e educacional. A tipologia do resseguro, sob os aspectos técnicos e formas de contratação, é tratada junto com o novo tipo de resseguro, o financeiro. Posteriormente, volta-se ao estudo do direito no resseguro, foco relevante desse trabalho, sem, todavia, pretender esgotá-lo, face à abrangência e natureza internacional desse instituto. São abordadas a natureza jurídica do contrato de resseguro, os princípios essenciais que o regem, bem como a estrita relação jurídica entre o segurador e ressegurador.

Por fim, enumera-se os principais fatos jurídicos e interesses envolvidos na quebra do monopólio, com a apresentação dos aspectos relevantes do resseguro constantes no novo Projeto de Lei Complementar. 


\section{Sumário}

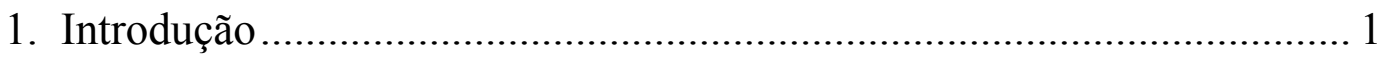

2. Seguro e Risco: conceitos fundamentas .............................................. 3

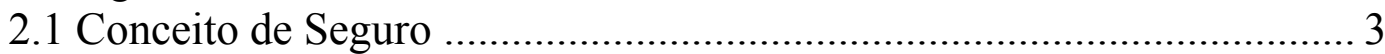

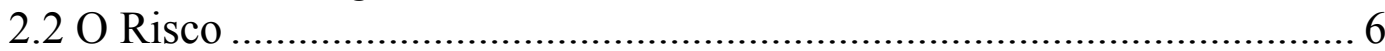

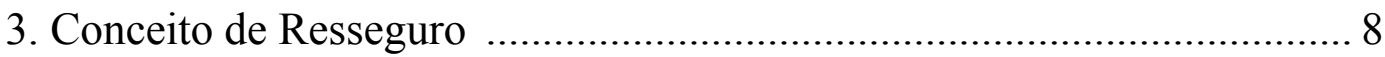

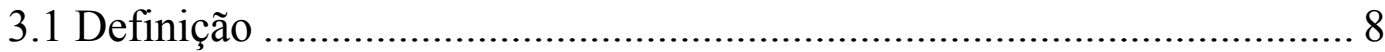

3.2 Função Primordial do Resseguro: a pulverização dos riscos ................. 10

3.3 O Co-seguro, a Retrocessão e Pools Ressecuritários …………….......... 13

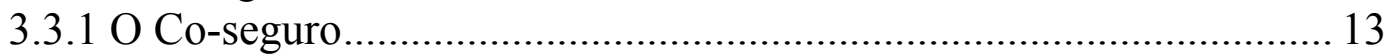

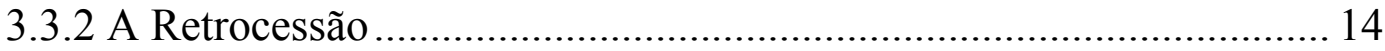

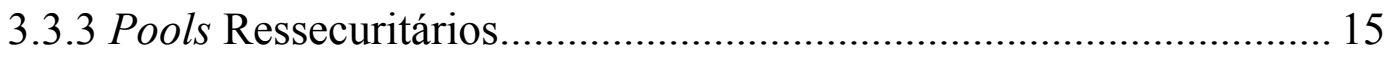

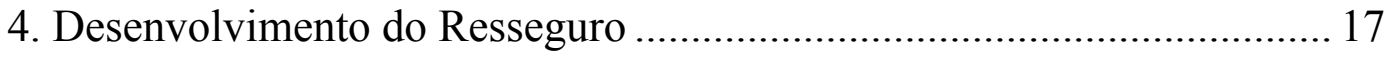

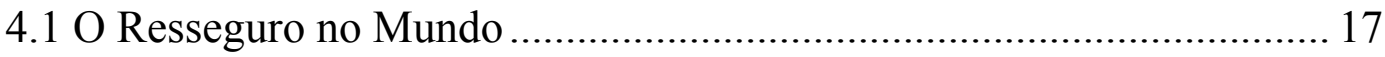

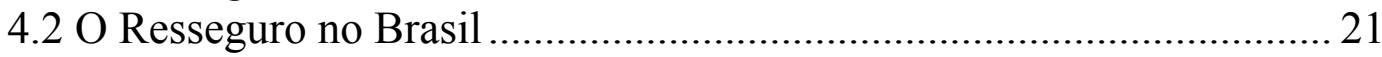

5. Funções do Resseguro: por que ressegurar?............................................. 28

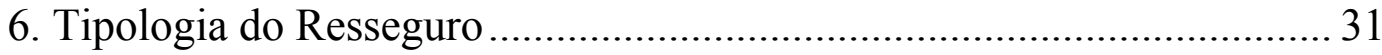

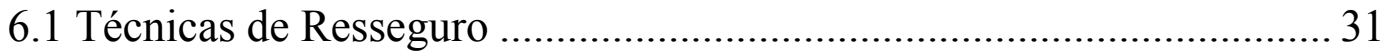

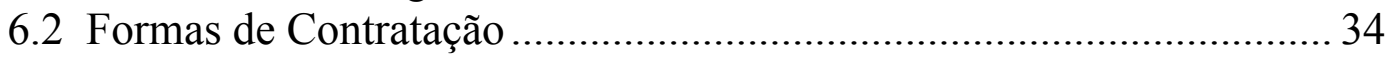

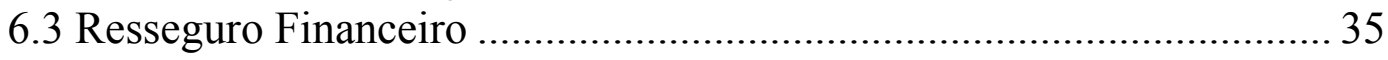

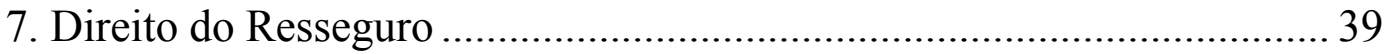

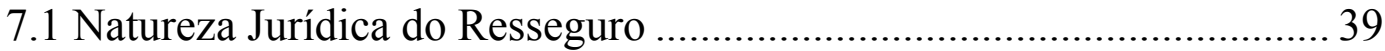

7.2 Resseguro como seguro de dano ...................................................... 41

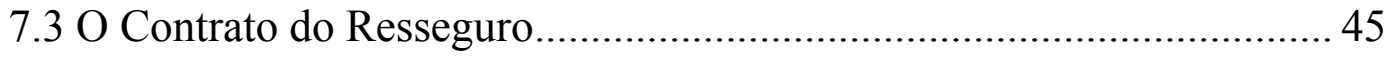

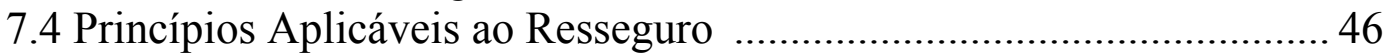

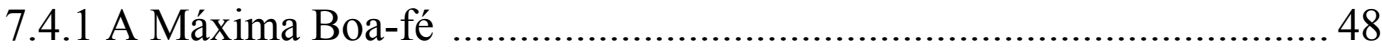

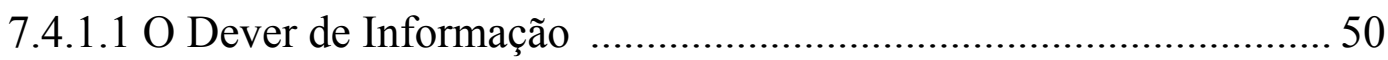

7.4.1.2 A Proibição Relativa ao Locupletamento Ilícito .................................51

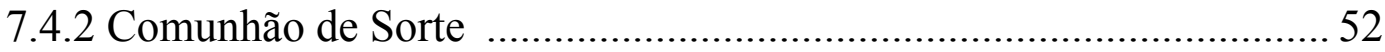

7.5 Ilegitimidade do Segurado frente ao Ressegurador................................54

8. Resseguro no Brasil e a Perspectiva de Abertura do Mercado................... 61

8.1 Proposta Inicial de Abertura no Mercado Ressegurador .......................... 61

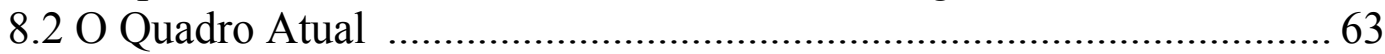

8.3 O Novo Projeto de Lei Complementar..................................................... 66

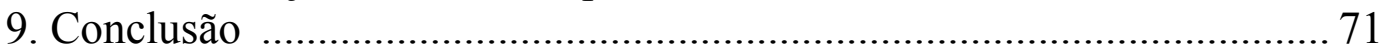

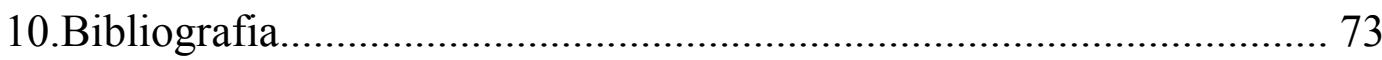

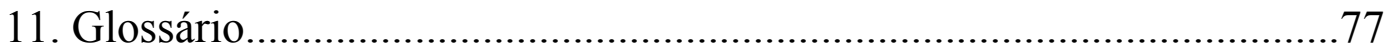

\section{ANEXO}




\section{Abreviaturas e siglas utilizadas}

CF - Constituição Federal

CPC - Código de Processo Civil

Dec. - Decreto

Des. - Desembargador

DJ - Diário de Justiça

ed. - edição

Ed. - Editora

ex. - exemplo

id. - idem

inc. - inciso

Min. - Ministro

n. - número

p. - página

$\S$ - parágrafo

RE - Recurso Extraordinário

RESP - Recurso Especial

RJ - Rio de Janeiro

RSTJ - Revista do Superior Tribunal de Justiça

Rel. - Relator

STF - Supremo Tribunal Federal

STJ - Supremo Tribunal de Justiça

TJ/SP - Tribunal de Justiça de São Paulo

TJ - Tribunal de Justiça, seguindo ao iniciais do Estado respectivo

vol. - volume 


\section{Introdução}

O resseguro é um produto comprado e vendido em todo o mundo, seja nos mercados monopolistas dos países em desenvolvimento ou com economia fechada, seja nos perfeitamente competitivos. Apesar da atualidade do tema, o conhecimento de seu significado e da importância de sua atuação na economia ainda é bastante reduzido.

Por ocasião dos últimos grandes sinistros ocorridos no planeta, o acidente com a plataforma P-36, de propriedade da Petrobrás, em 15 de março de 2001 e os atentados de 11 de setembro de 2001 nos EUA, o resseguro assumiu um lugar de destaque ao permitir que as severas conseqüências sobre a economia brasileira, no primeiro caso, e sobre a economia americana, no segundo caso, fossem amenizadas.Promovendo a dispersão dos prejuízos em escala mundial, o resseguro pulverizou os efeitos financeiros dos sinistros entre companhias de resseguros de diversos países.

Ao possibilitar que os sinistros sejam suportados, principalmente os de vulto, à nível mundial, o resseguro assume papel relevante na atividade econômica de uma nação, garantindo a absorção dos danos e prejuízos que venham a ocorrer. A necessidade de compartilhar certos riscos aceitos faz com que, freqüentemente, as seguradoras que operam sobretudo no mercado local, participem de negociações internacionais de resseguros, impossibilitando, em geral, uma clara divisão entre o mercado local e o mercado de resseguro internacional.

Por outro lado, observando-se o cenário político interno, a abertura do mercado segurador a partir de 1985 e a promulgação da Constituição de 1988, já sob a égide de uma economia de mercado, evidenciaram a necessidade do país adequarse a realidade internacional, dando início a um forte movimento político-econômico no sentido de acabar com o monopólio do resseguro detido, desde o Estado Novo, pelo IRB-Brasil Resseguros S/A. 
Atualmente, o resseguro é alvo de forte debate, em virtude do envio ao Congresso Nacional do Projeto de Lei Complementar $n^{\circ} 249 / 2005$, cuja finalidade é estabelecer um marco regulatório geral do mercado de resseguros e disciplinar sua abertura, propondo, finalmente, a quebra do monopólio estatal desse segmento econômico.

Na perspectiva da abertura de mercado de resseguros residem expectativas de instalação de novos resseguradores, que trarão consigo elementos para o aumento da retenção nacional e de capacidade de subscrição das seguradoras, e o conseqüente aperfeiçoamento dos agentes econômicos envolvidos. Além disso, espera-se o crescimento da demanda por especialistas no segmento de resseguros.

O presente trabalho, busca-se assim, sob o enfoque econômico-jurídico, contribuir para a divulgação e o conhecimento desse importante segmento da economia, em especial, tratar do resseguro no Brasil apontando as possíveis conseqüências da abertura do mercado. 


\section{Seguro e Risco: conceitos fundamentais}

A compreensão do instituto do resseguro pressupõe, de início, uma abordagem de dois conceitos que the são essenciais, o conceito de seguro e o de risco.

\subsection{Conceito de Seguro}

O seguro e o resseguro, ainda que institutos distintos, apresentam uma relação de interdependência entre si, de tal modo que para a boa compreensão do resseguro e suas características se faz necessário um apanhado da industria securitária.

$\mathrm{O}$ alicerce do seguro moderno é a chamada lei dos grandes números, descoberta em 1700 por Jacob Bernoulli, matemático da cidade da Basiléia, Suíça, e co-descobridor da teoria da probabilidade. A partir dessa técnica, é possível prever, dentro de um universo delimitado, composto por sujeitos interessados em um mesmo tipo de fato acidental, quantos deles, em um dado período, sofrerão efetivamente as conseqüências desse fato que lhes é comum e quais serão suas perdas. Com base nesses cálculos, estima-se o valor da contribuição de cada um dos sujeitos a fim de que aqueles que vierem a se defrontar efetivamente com o sinistro sejam indenizados das perdas ocorridas.

A validade das predileções probabilísticas depende da análise homogênea, qualitativa e quantitativa de um universo de indivíduos, em período mínimo de tempo, para que então seja determinado um comportamento médio e, portanto, a incidência de sinistro.

Nesse sentido, o sistema securitário pressupõe, para sua solvência, o atendimento a determinadas condições técnicas, tais como, uma grande massa de segurados, contratação de seguro de longo prazo, a homogeneidade da qualidade dos bens passiveis de danos na deflagração do risco, a identificação de riscos específicos, a promoção da dispersão física dos objetos dos seguros (cidades 
diversas), a obtenção de valores em riscos homogêneos (entre cinqüenta e cem mil e reais, por exemplo).

O seguro funda-se, portanto, no princípio do mutualismo, isto é, na idéia de comunhão de recursos por diversas pessoas para um determinado fim. As companhias seguradoras, mediante o agrupamento técnico do interesse individual ameaçado, promovem uma solidariedade implícita ao conjunto de maneira que esta financie o próprio sistema de reparação de sinistros, atuando como administradoras da mutualidade organizada segundo as leis da estatística.

Nesse sentido, Hemmard define:

"seguro é a operação pela qual, mediante pagamento de pequena remuneração, uma pessoa, o segurado, se faz prometer a si própria ou para outrem, no caso de realização de um evento determinado, a que se dá o nome de sinistro, uma prestação de uma terceira pessoa, o segurador, que assumido um conjunto de riscos, os compensa segundo as leis da estatística e o princípio do mutualismo."

Analisado sob o aspecto econômico, o seguro tem o escopo de restabelecer o patrimônio dos segurados na medida em que estes resultem afetados por riscos alheios às suas vontades. Sendo o segurado a pessoa física ou jurídica que, tendo interesse segurável, contrata o seguro em seu benefício ou de terceiros, e à qual o segurador assume sua responsabilidade.

No âmbito jurídico, o legislador brasileiro optou por reservar ao novo Código Civil, Lei $\mathrm{n}^{\mathrm{o}} 10.406$, de 10.01.2002, a estrutura do contrato de seguro, e à legislação extravagante, por ser mais flexível, "o casuísmo das minudências incidentes".

Alocado no Titulo VI, Das Várias Espécies de Contrato, encontramos dispositivos gerais (arts. 757 a 777), aplicáveis a todas as modalidades de seguros, e, em seguida, a divisão do contrato de seguro em duas categorias: seguro de dano (arts. 778 a 788) e seguro de pessoa (arts. 789 a 802). O artigo 757 dispõe:

\footnotetext{
${ }^{1}$ Apud ALVIM, Pedro. O Contrato de Seguro. $3^{\mathrm{a}}$ ed. Rio de Janeiro: Forense, 1999. p. 65.

${ }^{2}$ PEREIRA, Caio Mario da Silva. Instituições do Direito Civil. $11^{\mathrm{a}}$ ed. Rio de Janeiro: Forense, 2003. p. 452.
} 
"Art. 757 - Pelo contrato de seguro, o segurador se obriga, mediante o pagamento do prêmio, a garantir interesse legítimo do segurado, relativo a pessoa ou a coisa, contra riscos predeterminados".

Observe-se que a obrigação do segurador recai, em detrimento da teoria indenitária adotada pelo Código de Civil de $1916^{3}$, sobre o dever de garantir interesse legítimo do segurado. A obrigação do segurador não mais se restringe ao puro e simples pagamento da indenização, como explica Flavia Reis Pagnozzi:

\begin{abstract}
"A opção do legislador demonstra a superação de paradigmas contratuais clássicos, cimentados no individualismo e o indisfarçável prestigio da função social do contrato. Em outras palavras, a obrigação do segurador não mais circunscreve ao pagamento puro e simples da indenização, mas deve garantir o interesse legitimo do segurado, circunstancia que repercute de modo significativo na ampliação das obrigações a cargo do segurador obrigação de garantia - em especial porque acomoda interpretação extensiva em favor dos interesses do segurado."4
\end{abstract}

Tais normas que tratam do contrato de seguro, sobretudo o citado dispositivo, acabam por gerar reflexos, ainda que indiretos, no resseguro. Como será verá adiante, embora o resseguro esteja fundado na teoria indenitária, dada sua função econômico-social de garantir o negócio do segurador, o ressegurador não pode ignorar nas operações de resseguro individual, por exemplo, os aspectos atinentes ao contrato de seguro, tampouco as normas legais e regulamentares regentes do mesmo. Tendo em vista que, nesse caso, serão elas as bases de orientação para a fixação e extensão das obrigações do ressegurado, bem como, do quantum indenizatório.

Em suma, o seguro tem, por meio de contrato, a pretensão de transferir ao segurador as conseqüências economicamente desfavoráveis de um evento possível de atingir o segurado. Do que resulta ao segurador estabelecer uma mutualidade

\footnotetext{
${ }^{3}$ Código Civil de 1916 (Lei 3.071, de $1^{\circ}$ de janeiro de 1916) “Art. 1432 - Considera-se contrato de seguro aquele pelo qual uma das partes se obriga para com a outra, mediante a paga de um prêmio, a indenizá-la do prejuízo resultante de riscos futuros previstos no contrato."

${ }^{4}$ PAGNOZZI, Flavia Reis. Revista do IRB. Rio de Janeiro: jan/mar 2003. Ano 63. 291.
} 
preparada para absorver a materialização do risco, a fim de que o bem ou interesse jurídico seja garantido.

\section{$2.2 \quad$ O Risco}

Considerado um dos elementos essenciais do contrato de seguro, o risco é o evento futuro e incerto, seja quanto à sua realização seja quanto ao momento em que deverá ocorrer, independente da vontade das partes, e de cuja ocorrência resultem prejuízos de natureza econômica.

Nesse sentido, Vera Helena de Mello Franco, ressaltando o caráter essencial do risco ao instituto do seguro, chega a afirmar que "a idéia fundamental que norteia e justifica a operação de seguros é a prevenção do risco, aqui entendido como a probabilidade de que um acontecimento ocasione um prejuízo no sentido de ônus econômico para o segurado" 5

Sob uma ótica mais técnica, o risco é a expectativa de sinistro e se compõe da relação tríplice entre a coisa segurada, o evento compatível com a mesma e a probabilidade de ocorrência desse evento. A teoria da probabilidade exerce um papel especial, neste ponto, para a ciência securitária, pois, ao permitir a previsão da ocorrência de sinistro por meio de estatísticas de numerosos casos análogos, são obtidas as médias de sinistros de grandes grupos, observados seus padrões de freqüência, além das diversas causas e efeitos atuantes sobre os mesmos, os quais determinarão, por sua vez, o preço do risco assumido.

Enquanto para o segurado, o seguro é um mecanismo de transferência de risco a um terceiro segurador mediante o pagamento de prêmio, para o segurador, a administração combinada de riscos individuais redundará no objeto e no próprio paradoxo da atividade securitária, qual seja, quanto maior a exposição ao risco, menor é o risco efetivamente assumido.

\footnotetext{
${ }^{5}$ FRANCO, Vera Helena de Mello. Lições de Direito Securitário: Seguros Terrestres Privados. São Paulo:. Ed. Maltese, 1993. pág. 19
} 
$\mathrm{Na}$ atividade seguradora o risco pode apresentar-se em diversas acepções, significando tanto o objeto do seguro quanto o risco (ou riscos) contra o qual tal objeto é segurado, bem como a probabilidade desse risco causar uma perda ao interesse do segurado sobre o objeto do seguro.

Já no resseguro, o risco admite tal amplitude conceitual que é não só a possibilidade de diminuição ou desequilíbrio do patrimônio do seguradorressegurado, em virtude de este ter que indenizar seus segurados, como também a possibilidade de um resultado global negativo de um balanço ou de uma dada carteira de seguros. 


\section{Conceito de Resseguro}

Este capítulo tem por objetivo dar início ao estudo do instituto do resseguro, para tanto, serão abordados o conceito de resseguro e a sua função primordial de pulverização de riscos, bem como as outras principais formas de pulverização de riscos.

\subsection{Definição}

O resseguro é uma operação que visa à transferência de parte ou mesmo de todo o risco assumido por uma companhia de seguros, mediante preço ou uma porcentagem dos prêmios, a uma outra companhia.

Nessa operação, a companhia seguradora que transfere seus riscos é denominada de companhia cedente e a que os recebe, companhia resseguradora.

Da mesma forma que o segurado procura salvaguardar-se dos efeitos de determinados riscos por meio do seguro, assim procede o segurador, que, compartilhando a responsabilidade assumida por meio do resseguro, cede aqueles riscos que ultrapassam sua capacidade de retenção, resguardando-se dos prejuízos tecnicamente desaconselháveis.

Nas palavras Robert W. Strain, o resseguro é:

“A operação pela qual o segurador, mediante um pagamento previamente combinado (prêmio), concorda em indenizar a companhia cedente contra toda, ou parte da perda que esta última pode sofrer, em uma apólice ou apólices que tenham sido emitidas" 6

Paulo Luiz de Toledo Piza, analisando o resseguro tecnicamente afirma que:

“... se apresenta como meio pelo qual as empresas de seguro buscam homogeneizar e limitar as responsabilidades securitárias que assumem, no curso do exercício de sua

\footnotetext{
${ }^{6}$ Apud ELLIOT, W. Michael; et al. . Princípios de Resseguro. V. 1 Série Are 141. Tradução de Roberto Luiz Martins de Castro. Revisão de Maria Helena de Aguiar Huebra. Rio de Janeiro: Funenseg, 2001. 220 p. p. 2
} 
atividade empresarial, normalizando o comportamento de suas carteiras de riscos e garantindo-as dos desvios ou desequilíbrios que, como visto, afetam a freqüência, a intensidade, a distribuição temporal ou a própria importância atinente aos sinistros de tais riscos". 7

Assim, da mesma maneira que o seguro viabiliza a atividade econômica, o resseguro viabiliza o seguro ao promover a estabilidade das carteiras das cedentes.

Importa ressaltar, todavia, que o seguro e o resseguro são dois institutos jurídicos distintos. Embora guardem a mesma função econômica e que à companhia cedente caiba a direção do negócio no que concerne a política de subscrição de riscos e condução de sinistros, a resseguradora, em princípio, não possui qualquer relação jurídica com o segurado. A exclusiva relação jurídica entre ressegurador e segurador é, desde do século XIV, uma das principais características do contrato de resseguro, como mostraremos adiante.

Outro fator diferenciador da atividade resseguradora, é fato desta estar, à nível internacional, menos sujeita ao dirigismo estatal, e, por isso, gozar de maior flexibilidade. Não pesa sobre ela, em geral, o controle de preços atrelado à contratação de resseguro, o que permite uma rápida reação das companhias a conjecturas adversas, independentemente de pressões competitivas.

Nada obstante, é indispensável à companhia resseguradora uma gestão que agregue os prêmios pagos pelas cedentes, com base na contratação do resseguro, a uma administração atenta de sua carteira de riscos, no fim de garantir o lucro, elemento indispensável a sua solvência e sobrevivência.

Para tanto, tal qual as companhias seguradoras, a instituição resseguradora utiliza-se de alguns critérios técnicos, como a determinação de uma política de aceitação e subscrição de riscos, o chamado, underwrinting; a manutenção de relações de longo prazo com as seguradoras, no escopo de que seja feita a 
compensação entre períodos de bons e maus resultados no curso do tempo; a articulação de vários ramos de negócio de uma ou mais seguradoras; e a prerrogativa de retroceder riscos que excedam sua própria capacidade de retenção.

Pelo exposto, conclui-se que é o resseguro, em espécie, um mecanismo de pulverização de riscos, no qual a seguradora transfere a outrem, total ou parcialmente, o risco assumido.

\subsection{Função Primordial do Resseguro: a pulverização dos riscos}

A despeito de fazer-se posteriormente uma abordagem das funções específicas do resseguro, é relevante ressaltar que todas convergem, inclusive em qualquer que seja a modalidade de resseguro, para sua função primordial de proceder a pulverização de riscos no mercado internacional.

Em que pese a expressão "pulverização de riscos" simbolizar a distribuição das responsabilidades entre o maior número possível de seguradoras, seja por meio do co-seguro, do resseguro, ou da retrocessão, temos que o resseguro exerce, por excelência, tal função.

Como visto, a operação de seguros demanda uma grande massa de negócios segurados aliada ao atendimento de determinadas condições técnicas para que se atinja uma homogeneidade (princípio da homogeneização) e estabilidade nas carteiras das seguradoras. Ocorre, porém, que "a Matemática não é perfeita e, além disso, a Estatística pressupõe um universo de condições que apenas em tese podem ser plenamente alcançadas."

Deste modo, mesmo que as seguradoras conseguissem captar uma massa de contratos suficientemente grande para atender simultaneamente a todas as condições técnicas ideais já assinaladas no item 2.1, o que é impossível ${ }^{9}$, estariam sujeitas a

\footnotetext{
${ }^{8}$ Piza, Luiz Paulo de Toledo e outros. Seguros: uma questão atual. São Paulo: Editora Max Limonad, 2001. p.

${ }^{9}$ Imagine-se formar uma carteira composta por dez mil edifícios, todos de um andar, todos dedicados à moradia, todos de com cem metros quadrados de área construída, de mesma qualidade de construção, mesma idade, com vizinhos iguais e localizados em trinta cidades diferentes
} 
fatores passíveis de modificar o comportamento previsto para cada conjunto de riscos. Esses fatores, que produzem desequilíbrio na composição das carteiras das seguradoras (vida, automóvel, responsabilidade civil, etc), são os chamados desvios atuariais, e são capazes de levar a insolvência de uma seguradora.

Costuma-se agrupar os desvios atuariais sob a rubrica dos seguintes riscos: risco de flutuação aleatória (ocorrência em um único ano de sinistros previstos para acontecerem de modo disperso ao longo de 10 anos); risco de catástrofe (a simultaneidade da exposição ao certo risco de um grande número de bens segurados a serem afetados em conjunto, concentração no tempo e espaço, como queda de aeronave no perímetro urbano); risco de erro (equivoco na interpretação das estatísticas pelo segurador); risco de mudança (progresso tecnológico, mudança no entendimento jurisprudencial) ${ }^{10}$

Ademais, ainda que não ocorra desvio de probabilidade, o fato da assunção de riscos de diferentes valores financeiros, por si só, é suficiente para conduzir uma seguradora a insolvência.

Ao se defrontarem com situações como as expostas, as seguradoras resguardam-se por meio de contratos de resseguro de diversas modalidades de técnicas ressecuritárias. Com base na combinação de diversas formas de resseguro, protegem-se das conseqüências econômicas negativas de quaisquer dos fatores de desvio ou de desequilíbrio atuarial constantemente presentes no âmbito da atividade securitária.

O segurador direto, ao assumir com exclusividade a responsabilidade de cobertura do risco perante o segurado, retém uma parcela da garantia dada conforme as condições técnicas de sua carteira, e cede o excesso sob a forma de resseguro. Ao passo que a resseguradora, ao suportar parte substancial dos riscos cedidos, atua amplificando a mutualidade no intento de distribuir os riscos vultuosos no mercado,

\footnotetext{
${ }^{10}$ Recentemente no Brasil deu-se uma mudança no entendimento jurisprudencial com relação ao risco de dano pessoal, que passou a ser entendido não apenas como danos físicos à pessoa, mas também danos morais. O contrato de responsabilidade civil por danos automobilísticos, por exemplo, não possuía bases estatísticas para sufragar o novo entendimento, de modo que este resultaria em perdas às seguradoras as quais não poderiam ser compensadas.
} 
e, com isso, gerar à cedente uma capacidade de oferta de seguro cada vez mais ampla e diferenciada.

Nesse ínterim, o sistema de resseguro encontra-se gerido por dois princípios, o da atomização global dos riscos e da substituição. Instituem a idéia de que através da ampla repartição global de cada operação de seguro, utilizando-se do maior número de canais possíveis, aliada a um processo de compensação das conjunturas desfavoráveis (princípio da substituição), é possível que as companhias resseguradoras atinjam um equilíbrio dos resultados e das suas contas.

Assim, a partir da distribuição internacional dos riscos a conjuntura desfavorável de um determinado país é compensada por uma mais favorável de outro, trazendo um equilíbrio nos resultados das carteiras de resseguro, e, por conseqüência, perenidade ao mercado segurador.

O caráter internacional do resseguro remonta, pois, a idéia de uma gerência internacional de riscos incorporada às leis da probabilidade, ou seja, uma distribuição geográfica dos negócios sopesando-se o eventual acúmulo de riscos entre as regiões. Sem embargo, pode o mercado ressegurador também atuar na diversificação das carteiras pelos ramos e tipos de seguro, a fim de que sejam compensados os períodos de bons e maus resultados de uma por outra.

Em função do exposto, pode-se afirmar que o resseguro tem por finalidade conferir estabilidade técnica e financeira às companhias seguradoras, e, em última análise, a promoção da mutualidade em sentido amplo, isto é, entre as seguradoras e resseguradoras. O que, para tanto, pressupõe uma escala de atuação tamanha que uma localidade, um único país, não basta para o seu sucesso.

Assegura Marcelo Haddad, com muita propriedade, que é da pulverização de riscos "que remonta a verdadeira internacionalização do resseguro, talvez um dos institutos jurídicos mais internacionais que existam hoje em dia". ${ }^{11}$

No Brasil, apesar da existência de ressegurador local monopolista, leia-se IRB - Instituto de Resseguros do Brasil, a quem todo e qualquer tipo de risco é

\footnotetext{
${ }^{11} \mathrm{O}$ resseguro Internacional pág. 11
} 
repassado, a função pulverizadora do resseguro sempre foi reconhecida, inclusive por lei, como dispõe o artigo $4^{\circ}$ do Decreto-Lei 73, de 21 de novembro de 1966: “integra-se nas operações de seguros privados o sistema de co-seguro, resseguro e retrocessão, por forma a pulverizar riscos e fortalecer as reações econômicas do mercado".

\subsection{O Co-seguro, a Retrocessão e Pools Ressecuritários}

\subsubsection{O Co-seguro}

Segundo Paulo Botti "o cosseguro é feito quando duas ou mais companhias de seguros repartem entre si suas responsabilidades perante o segurado" 12

Esta operação consiste na repartição de um mesmo risco, de um mesmo segurado, entre duas ou mais companhias seguradoras. Os vários seguradores diretos concedem a cobertura do segurado em conjunto, por meio de tantas apólices quantos forem ou como co-signatários de uma apólice, em que cada qual responsabiliza-se perante o segurado diretamente e apenas em sua cota-parte.

Em geral, quando há uma única apólice transfere-se determinados poderes de gestão à companhia de seguro líder, a qual está autorizada a representar todas, fato este que não altera a existência de relação jurídica direta entre cada co-segurador e segurado.

Pedro Alvim compara o sistema de co-seguro com o resseguro dizendo:

"Exerce, pois o resseguro função essencial à estabilidade técnica do segurador, pois facilita
a homogeneização dos riscos de suas diferentes carteiras de operação. O mesmo resultado
poderia ser alcançado pelo cosseguro, desde que não se aceitasse responsabilidade superior
à sua capacidade de retenção. Mas isso poderia criar dificuldades para o segurado que teria
de tratar com diversos seguradores e seria comercialmente contraproducente para o próprio
segurador ao revelar suas limitações de negócio, expondo-se à concorrência de congêneres.

${ }^{12}$ Botti, Paulo Eduardo de Freitas. P. 25 
A operação de resseguro, independendo da intervenção do segurado, oferece condições de operar-se com eficiência e rapidez, sem prejuízo da atividade comercial do segurador" ${ }^{13}$

\subsubsection{A Retrocessão}

A retrocessão é a operação na qual a companhia resseguradora cede parte das suas responsabilidades aceitas a outra ou outras resseguradoras.

A companhia resseguradora ao se deparar com grande acúmulo de riscos e volume de responsabilidades capazes de afetar sua estabilidade financeira deverá, baseada nos princípios da substituição e atomização dos riscos, promover a compensação dos mesmos a fim de proteger-se.

A resseguradora quando cede alguns riscos ao retrocessionário faz o mesmo com os respectivos prêmios, gerando para esse o compromisso de garantir, à medida convencionada, a atividade ressecuritária.

Para Pedro Alvim a retrocessão é “a operação em que o ressegurador procura colocar seus excedentes, seja para o mercado interno junto a congêneres, seja para o exterior através de convênios"14

$\mathrm{Na}$ retrocessão, em geral, não se ressegura riscos específicos, mas sim tratados firmados entre o seu ressegurado com os seguradores-ressegurados. Por este motivo, o retrocessionário não costuma perquirir as particularidades de todos riscos e tampouco a política de gestão e liquidação de sinistros assumidos pela retrocedente em resseguro.

Paulo Luiz de Toledo Piza define retrocessão:

\footnotetext{
"Trata-se de um contrato que pode ser celebrado com um outro ressegurador, por riscos individuais ou mediante tratados, valendo aduzir que o retrocessionário, por sua vez, pode repartir os compromissos por ele assim assumidos, mediante a celebração de tratados de segunda ou terceira retrocessão, por exemplo". ${ }^{15}$ :
}

\footnotetext{
${ }^{13}$ ALVIM, Pedro. O Contrato de Seguro. Editora Forense. Rio de Janeiro: 1999, p. 358.

${ }^{14}$ Alvim, como pág. 365

${ }^{15}$ Paulo Luiz de Toledo Piza: pág. 294
} 


\subsubsection{Pools Ressecuritários}

Os pools ressecuritários tem por objetivo a assunção, em resseguro, de riscos de grande vulto e particularmente graves, seja em função de suas dimensões econômicas, seja atinentes a ramos específicos, tais como, os riscos nucleares.

Trata-se de uma organização formada no intuito de coordenar a atividade ressecuritária em dado setor direcionando uma política empresarial comum aos integrantes. As companhias consorciadas cedem ao pool os riscos previstos contratualmente, e este os divide proporcionalmente conforme a participação de cada uma das resseguradoras.

São, por conseguinte, arranjos que tomam por base a disciplina dos consórcios no fim de repartir entre si não só os resultados, como também as perdas decorrentes da atividade ressecuritária individualmente desenvolvida.

No Brasil, compete ao IRB a organização e administração de consórcios. Como exemplo, podemos citar o Consórcio Brasileiro de Riscos Nucleares (CBRN), em que há a participação do IRB e a adesão compulsória das seguradoras brasileiras que operam em ramos elementares. Os riscos aceitos em seguro direto são integralmente ressegurados no Consórcio que por sua vez os repassa aos seus participantes, na proporção dos limites técnicos das companhias seguradoras, cabendo ao IRB com um percentual fixo sobre os negócios ressegurados. 


\section{4- Desenvolvimento do Resseguro}

Será abordado nesse capítulo os aspectos históricos e a evolução da instituição resseguradora no mundo e no Brasil.

\subsection{O Resseguro no Mundo}

O primeiro contrato de resseguro de que se tem prova documentada surgiu na Itália renascentista, no bojo do desenvolvimento do transporte de seguros marítimos, onde já se fazia uso de contratos de empréstimo chamados "bottomry bonds", cujo objetivo era financiar a compra da mercadoria e o risco do transporte.

Afirma-se que uma crise de confiança na pessoa do segurador, sobretudo diante da impossibilidade de arcar financeiramente com os riscos vultosos assumidos de forma individual, somada ao fato do segurador arrepender-se após assinar uma apólice de seguro, teriam dado azo ao surgimento do resseguro.

Assim é que em 12 de julho de 1370, na cidade de Gênova, Martino Marcuffo e Godofredo di Benavia (resseguradores) assumiram obrigação junto a Giuliano Grillo (segurador), que se obrigara a comprar determinadas mercadorias de Giovanni Sacco (segurado), caso estas, que partiam do porto de Gênova, sofressem alguma avaria ou não chegassem ao porto de d'Écluse (Sluis), região de Flandres. $\mathrm{Na}$ eventualidade de ocorrência de acidente no trecho da viagem considerado mais perigoso, entre Cádiz (Andaluzia), costa atlântica da Espanha, e o porto de destino no Mar do Norte, os resseguradores se comprometiam a comprar tais mercadorias.

Impõe-se ressaltar que, desde o início, já era possível identificar uma das principais características do contrato de resseguro, qual seja, a relação exclusiva entre ressegurador e segurador, sem qualquer vínculo entre segurado e ressegurador. 
Embora essa atividade de transferência de riscos tenha iniciado oficialmente em 1370, e, gradativamente, se tornado uma prática comum, fosse para a diminuição do risco ou para uma maior participação em número de negócios sem o imperativo do aumento de capital, o resseguro esteve durante muito tempo sob a imagem do coseguro, ainda que garantisse aos seguradores maior flexibilidade e vantagens econômicas.

Durante esse período, aproximadamente 500 anos, a falta de entidades especializadas conduzia os seguradores a realizarem acordos entre si, aparentes ou não para os segurados, conforme o caso.

Os grandes incêndios ocorridos em Londres e Berlim, no século XVII, acabaram por gerar de tal modo um desenvolvimento das operações de seguro de Incêndio, que aos seguradores tornou-se imperiosa uma capacidade complementar através do resseguro, a fim de dar vazão a demanda crescente por essa nova modalidade de seguro.

Nessa época, também verifica-se o nascimento das primeiras normas específicas sobre resseguro. Na Antuérpia, os "Costumes" datados de 1609 mencionavam a figura do resseguro e na França, em 1681, foi promulgada a “Ordonnance de la Marine”, permitindo a assunção de riscos em resseguro, a qual foi posteriormente incorporada ao Código Napoleônico.

Nos anos de 1746 a 1864 o resseguro foi proibido na Inglaterra em função das práticas abusivas do mercado inglês. Pelo sistema denominado "Difference in premium", o segurador direto subscrevia riscos, ressegurando-os depois, integralmente, a um prêmio inferior ao original, ou seja, auferia ganhos vultuosos sem o correspondente risco. A partir desse período, o resseguro na Inglaterra passou a ser permitido apenas para o caso de morte ou insolvência do segurador, o que redundou não só na redução da capacidade de aceitação dos seguradores, como 
também incrementou o desenvolvimento dos negócios dos subscritores particulares do Lloyd's. ${ }^{16}$

Por volta de 1850, sugiram as primeiras companhias resseguradoras profissionais, sendo a Kölnische Rückversichenrungs-Gesellscahft (Companhia de Resseguros de Colônia), criada em 1846, em decorrência do incêndio de 1842 na cidade de Hamburgo, Alemanha, a primeira entidade exclusiva de resseguros.

Nas décadas subseqüentes foram fundadas outras companhias de resseguro independentes e especializadas, também chamadas "resseguradoras profissionais". Duas dessas companhias adquiriram uma posição de destaque no mercado: a Companhia de Resseguros de Munique e a Companhia de Resseguros da Suíça. Foram criadas, ainda, as chamadas sociedades de resseguro intra-companhia cujas ações encontravam-se integralmente, ou na sua maior parte, nas mãos das sociedades de seguro direto, que passaram os seus negócios de resseguro em parte ou inteiramente para as mesmas.

Com a industrialização crescente, a interdependências das economias e o desenvolvimento de novos tipos de seguro (acidentes pessoais, responsabilidade civil, automóveis e quebra de maquinários) as sociedades de resseguro alcançaram um caminho de prosperidade considerável. ${ }^{17}$

\footnotetext{
16 O Lloyd's surgiu em 1688, num modesto café, situado na Lombart Street, Londres, de propriedade de Edward Lloyd. A proibição do resseguro marítimo ocorreu no exato período em que a Inglaterra tornava-se líder no mercado mundial de seguros, o que leva a crer que tal proibição atendia precisamente aos interesses do Lloyd's, concentração ímpar de seguradores individuais organizados em cooperativas, a qual se tornaria uma das mais importantes instituições de seguros do mundo, ainda hoje com grande prestigio. Embora atualmente seja um mercado de resseguros importante, a atuação dos membros do Lloyd's deu-se, de início, como co-segurador, e foi claramente desenvolvido a partir desse período, quando, o seu sistema de repartição primária do risco transformou-se no método predominante de repartição, inclusive no caso de riscos de grande porte. Ressalta-se que o Lloyd's não constitui propriamente uma sociedade, mas uma bolsa de seguradores profissionalmente organizada e subordinada a um comitê central, de caráter administrativo, cuja missão é zelar pela aplicação do seu regulamento interno. As apólices subscritas pela entidade pertencem a um ou mais grupos, de dois a quarenta underwriting membres. Cada um é representado por um underwriter que aceita em nome de todos o risco por meio dos brokers, repartindo-o posteriormente entre seus membros. Não há solidariedade entre os membros, respondendo cada qual por sua parcela de subscrição.

${ }^{17}$ Cumpre ressaltar a importância e capacidade das sociedades de resseguro alemães, que privadas das suas relações comerciais com o exterior, logo após as duas grandes guerras, e fortemente atingidas pela desvalorização de seus ativos em conseqüência dessas, conseguiram recuperar, em ambas ocasiões, rapidamente, sua posição de liderança mundial.
} 
Adiante, o mercado ressegurador, mais consolidado, empenhou-se em diversificar sua atuação, buscando uma internacionalização de seus negócios. Assim, não só sobreviveu aos conflitos mundiais, como se desenvolveu junto às economias nacionais, adaptando-se à evolução tecnológica e, portanto, à conseqüente diversificação de riscos. Aqui entendidos como os riscos de petróleo, indústria farmacêutica, desenvolvimento da energia nuclear, exploração do espaço, etc.

Após a Segunda Guerra Mundial, o resseguro passou por modificações importantes, primeiro porque o novo ordenamento imposto pelo lado aliado proibia as atividades no exterior dos resseguradores alemães, segundo que nos países sob o controle comunistas estabeleceram-se instituições de seguros estatais que prescindiam quase completamente do resseguro, e, por fim, foram estabelecidos em diversos países monopólios estatais de resseguro (a exemplo do Brasil, Peru, Uruguai e Irã), os quais praticamente inviabilizaram as possibilidades de negócios de outras resseguradoras.

Assistiu-se, nas últimas décadas, o desenvolvimento de novas técnicas de resseguro. As companhias resseguradoras, no intuito de mitigar os riscos de suas parceiras quando estas, por questões de mercado, se viam impedidas de cobertura pelo resseguro tradicional, desenvolveram técnicas alternativas de transferência de riscos, dentre as quais o resseguro financeiro, a ser tratado adiante.

Recentemente, o fato ocorrido no dia 11 de setembro de 2001, que deixou em seu rastro milhares de vidas perdidas, destruição maciça de bens e perdas financeiras de dezenas de bilhões de dólares, mostrou a necessidade de o seguro e o resseguro se tornarem mais técnicos, com maior severidade nas análises para as discriminações de coberturas, as cláusulas de exclusão, sobretudo de terrorismo, e fez com que as taxas de seguro e resseguro se elevassem para reporem os prejuízos advindos do maior sinistro provocado pelo homem até os dias de hoje. 


\section{2- O Resseguro no Brasil}

A evolução da instituição do seguro e resseguro no Brasil acompanhou desenvolvimento econômico conforme ocorreu no mundo, tendo sido pouco significativa enquanto permaneceu-se na situação política de Colônia.

$\mathrm{Na}$ sua trajetória até a República é relevante destacar que a estruturação e organização da atividade securitária deu-se mais como uma dinâmica da vida econômica e da evolução da consciência do risco, do que como uma instrumentação implantada com a finalidade de auxiliar essa atividade. O resseguro até então era realizado quase totalmente no exterior, de forma direta ou por intermédio de companhias estrangeiras que operavam no Brasil.

O Estado normatizador e fiscalizador somente passa a intervir quando o mercado de seguros adquire complexidade e diversidade nos negócios, demandando um mecanismo de modulação de interesses. Normas que atendendo aos superiores interesses do País, ditadas pela conjuntura histórica, visavam, principalmente, reter um maior volume possível de negócios em nossa economia.

Assim é que no Estado Novo, após a Revolução de 1930 liderada por Getúlio Vargas, em um contexto cerradamente estimulado por aspirações nacionalista, medidas de grande profundidade foram alvo de debate no Congresso no que se refere ao mercador segurador.

A Constituição de 1934 (art. 111) previu a nacionalização das sociedades de seguros em todas as suas modalidades, e a Constituição de 1937, atribuiu privativamente à União a competência para legislar sobre seguros e sua fiscalização (art 15, XVII), bem como a nacionalização das empresas de seguros (art. 145).

Nesse sentido, a idéia de se criar um organismo regulador das operações de resseguro mostrou-se oportuna ao objetivo de nacionalização das empresas estrangeiras, vez que o controle do resseguro atingiria, direta ou indiretamente o foco do problema, que era a evasão de divisas para o exterior. 
Para a implantação do monopólio do resseguro no país foi criado, através do Decreto-Lei n ${ }^{\circ}$ 1.186, de 03.04.1939, o IRB - Institutos de Resseguros do Brasil, uma sociedade de economia mista, que, em perfeita simbiose com DNSP Departamento Nacional de Seguros Privados e Capitalização, subordinado ao Ministério do Trabalho, da Indústria e do Comércio, concretizou a nova orientação do setor de seguros no âmbito nacional.

O Decreto, ao dar a natureza de sociedade de economia mista, tornou obrigatoriamente sócias as seguradoras em operação no país, e estabeleceu, inclusive, que as mesmas seriam obrigadas a ressegurar no IRB as responsabilidades excedentes de sua retenção.

Em 1940, com a efetiva instalação do IRB, foi sedimentada a proposta político-econômica de proteção do mercado brasileiro, possuindo como desafios operacionais a regulamentação do resseguro e o fomento às operações de seguros em geral.

De fato esse órgão se tornou peça fundamental no mercado segurador brasileiro, orientando sua política no sentido de fortalecer as seguradoras nacionais por meio da criação de condições de competitividade, com o estabelecimento de baixos limites de retenção e de um excedente único.

Embora determinada seguradora fosse de pequeno porte, poderia assumir riscos de grande vulto, pois o que excedesse sua capacidade seria automaticamente transmitido ao ressegurador. Permitindo-se assim, a homogeneização da carteira da seguradora e aumento da sua capacidade de produção.

O IRB, dessa forma, atendeu rápida e plenamente aos anseios políticoeconômicos da nação, com operações expressadas em números bastante significativos. Após nove meses de atuação, conseguiu reter no país cerca de noventa por cento $(90 \%)$ dos prêmios de resseguros-incêndio praticados. Tal ramo 
de seguro foi seu foco inicial de atuação no mercado, pois era responsável pelo maior volume de seguros, cerca de setenta e cinco por cento (75\%) do valor total de todas as modalidades exploradas na época.

No ano de 1941, o Decreto-Lei 3.784 tornou obrigatória às sociedades seguradoras a aceitação das retrocessões do IRB, mesmo nos ramos não operados por elas. Ao IRB atribuiu-se a obrigação de retroceder ao mercado interno, isto é, às seguradoras, os excedentes da retenção dele próprio.

Em síntese, quanto à possibilidade de atuação no mercado segurador da época, o IRB poderia: receber como ressegurador, além dos resseguros automáticos (obrigatórios), os resseguros facultativos do país ou do estrangeiro retendo parte dos riscos e, como retrocedente, distribuir pelas sociedades, nas proporções das respectivas retenções, as responsabilidades excedentes, ou ainda colocar no exterior os riscos que sem cobertura no país.

Gradativamente, novos ramos foram sendo incorporados pelo Instituto, com destaque para o seguro aeronáutico, que foi implantado no Brasil em janeiro de 1944.

Durante a Segunda Guerra o IRB participou, juntamente com todas as sociedades resseguradoras que operavam no ramo de transporte, de um pool referente aos riscos de Guerra, para o qual as companhias seguradoras passaram a ceder integralmente suas responsabilidades.

Até o ano de 1948, as relações com mercado exterior eram limitadas à cessão de responsabilidades. A partir dessa data, iniciou-se uma fase de operações em larga escala entre o Instituto de Resseguros do Brasil e o mercado de resseguro de todo o mundo. 
A partir da década de 50, o Instituto passou a aceitar solicitações de resseguro sobre riscos para os ramos de acidentes pessoais, vida, cascos, automóveis, lucros cessantes e, além disso, instituiu a cobertura sobre seguro agrário.

No cumprimento do objetivo de desenvolver as operações de seguros no país, o IRB promoveu, entre as décadas de 40 e 60, a consolidação do mercado segurador, do que resultou um acentuado crescimento do número de seguradoras nacionais $\mathrm{e}$ estrangeiras, saltando de 74, entre 1905 a 1939, para 143 a partir de então.

Acompanhando o desenvolvimento econômico, o mercado segurador brasileiro e a atividade de resseguros tiveram suas bases ainda mais solidificadas durante a década de 70. Nesse período, o IRB procurou incentivar o processo de fusões e incorporações de seguradoras para uma maior economia de escala nas operações securitárias, consolidando, desse modo, o seguro como meio de captação de poupança interna.

Após a crise do petróleo na década de 70, o Instituto e as seguradoras brasileiras iniciaram, a fim de atrair moeda forte ao país, a aceitação de resseguro no exterior, o que, contudo, foi interrompido em 1984, após grandes perdas.

Não obstante o inegável êxito da atuação do IRB, com o passar do tempo, seu modelo monopolista e centralizador começou a dar mostras de esgotamento, não mais atendendo plenamente às novas exigências do mercado.

Concebido para ser essencialmente uma instituição ocupada com o resseguro, o IRB vinha assumindo um caráter de órgão fiscalizador, exorbitando suas funções, chegando, até mesmo, a inibir a criatividade e a livre concorrência entre as empresas do setor.

Com a edição do Decreto-lei 73, de 21.11.1966, o governo brasileiro instituiu o Sistema Nacional de Seguros Privados, constituído pelo Conselho Nacional de 
Seguros Privados (CNSP), Superintendência de Seguros Privados (SUSEP, criada nesse Decreto), IRB-Brasil Resseguros S.A., Companhias Seguradoras e Corretores de Seguros.

Coube, a partir de então, à SUSEP a função de órgão controlador e fiscalizador da constituição e funcionamento das sociedades seguradoras e entidades abertas de previdência privada. E o IRB, que praticamente exercera funções hegemônicas na definição das características das operações de seguros no Brasil, passou a dividir com a Superintendência algumas de suas antigas atribuições.

Em 1985, a transição do regime militar para a democracia trouxe consigo um processo de desregulação próprio do pensamento neoliberal, o qual significaria para o mercado de seguros brasileiro o fim do "entulho legal autoritário", que tanto limitava seu desenvolvimento. A SUSEP, nesse período, dá início a uma fase de profundas transformações, visando à criação de condições de liberdade e realismo contratual $^{19}$, no intuito de promover o crescimento do mercado em um ambiente de justa e desejável concorrência.

Nesse processo, a Constituição Federal de 1988 trouxe alguns avanços ao mercado segurador como um todo, elevando o seguro, a capitalização e a previdência privada a um novo status. Nos termos do Art. 21, essas atividades

\footnotetext{
${ }^{18}$ Vide, nesse sentido, Dilemas da Política de seguros na Nova república. Entre a solidariedade e o risco: história do seguro privado no Brasil. p. 244.

${ }^{19}$ Nesse sentido: "Assumindo na plenitude suas funções de reguladora do mercado segurador, a SUSEP implanta o sistema de audiência pública e aberta a todos os segmentos, para a formulação de medidas gerais e tomada de decisões. Promove a desregulação gradual da atividade seguradora, e atendendo a expresso desejo das empresas, que pediam mais liberdade para suas operações, dá autonomia à criação de produtos. Estimula a formação de empresas regionais. Modifica os critérios e requisitos para aplicação de reservas técnicas em ativos mobiliários. Acaba com a exigência de carta-patente para o funcionamento das seguradoras. E para enfrentar a realidade da inflação que corroía valores segurados, promove a indexação dos contratos, que passam a ser atualizados com base na correção monetária." Disponível em http://www.fenaseg.org.com.br//. Acessado em 18/03/2005.
} 
passaram a integrar o Sistema Financeiro Nacional ao lado das demais instituições que, desde então, aguardam a regulamentação de suas atividades, previstas no art.192 da Constituição.

No ano de 1992, a Carta de Brasília, apresentada pela Fenaseg (Federação Nacional das Empresas de Seguros Privados e Capitalização), seguida do Plano Diretor do Sistema de Seguros, Capitalização e Previdência Complementar, representaram um marco na história da atividade de seguros privados no país. Numa ação coletiva do empresariado com o governo, reafirmou-se não só a importância da desregulamentação do setor, como a necessidade de modernização da atividade seguradora. No que diz respeito à atividade resseguradora, o Plano previa uma reestruturação do IRB com a gradual redução do monopólio até sua final extinção. O IRB seria, assim, preparado para competir no mercado como uma empresa de resseguros privada, eficiente e competitiva.

Em agosto de 1996, o Congresso Nacional, através da Emenda Constitucional $\mathrm{n}^{\circ} 13$, aprovou a quebra do monopólio para a atividade de resseguro no Brasil delegado exclusivamente ao IRB.

A eficácia da Emenda depende, entretanto, de regulamentação por lei complementar, para que enfim o mercado de resseguro, questionador dessa política monopolista há mais de uma década, possa operar livremente, tema que será abordado no último capítulo do presente trabalho. 


\section{Funções do Resseguro: por que ressegurar?}

A doutrina ressecuritária confere ao resseguro, além de sua função primordial de pulverização de riscos já mencionada, as funções mercadológica, gerencial, financeira e educacional.

Se o seguro é uma forma de transferência do risco de perda financeira para uma companhia seguradora, o resseguro vem a viabilizar este negócio na medida em que visa transferir uma parte desse risco a uma outra companhia, permitindo desde a proteção da companhia cedente ao aprimoramento técnico, através do intercambio de know-how com outras seguradoras e resseguradoras.

Nesse ínterim, Paulo Botti ${ }^{20}$ ensina que o resseguro, para ter alguma valia para a companhia que o compra, deve exercer, no mínimo, uma de suas quatro funções.

A função mercadológica ou proteção vertical traduz-se na geração de capacidade para a seguradora cedente e decorre da sua necessidade conquistar mercado, ou seja, verte-se a gerar capacidade operacional de forma a alavancar os negócios das cedentes.

O resseguro nessa função atua aumentando a capacidade individual de aceitação de riscos a fim de permitir à seguradora subscrever riscos maiores que sua capacidade de retenção. E, por conseqüência, promove um equilíbrio de forças entre as pequenas, médias e grandes companhias dentro de determinado mercado.

A função gerencial do resseguro ou proteção horizontal (balance sheet) objetiva proteger diretamente a companhia cedente e indiretamente seus clientes originais, isto é, os seus segurados.

Em vista da alternância de períodos bons e ruins no desenvolvimento normal das carteiras de seguros, a existência do resseguro permite a companhia seguradora

\footnotetext{
${ }^{20}$ BOTTI, Paulo Eduardo de Freitas. Introdução ao Resseguro (para brasileiros). São Paulo: Nobel, 1995. p. 155
} 
absorver a um nível mais aceitável as flutuações de resultados ocasionadas por ciclos de eventos negativos e positivos, e de eventos catastróficos, como também reduzir, proporcionalmente, a variação de preços nessas ocasiões para os consumidores de seguros.

A companhia resseguradora funciona, nesse caso, como um sócio, quando equilibra e distribui entre as duas partes os resultados dos períodos de lucro e de prejuízo, e, como um verdadeiro financiador, quando absorve o impacto financeiro negativo no ano em que a catástrofe ocorre, amortizando esse custo em vários anos, através do pagamento do prêmio do resseguro antes e após o ocorrido.

O resseguro propõe-se, portanto, a mitigar os efeitos das flutuações de resultados nos negócios das companhias seguradoras, permitindo uma constante de crescimento.

$\mathrm{Na}$ função educacional o resseguro age freqüentemente como elemento de aprimoramento na troca e disseminação de novas tecnologias securitárias, na assessoria e na capacitação das companhias seguradoras.

No anseio de maximizar os negócios, as resseguradoras repassam know-how às seguradoras e produtos já experimentados em outros países, desenvolvem novos, bem como, assessoram nas políticas de subscrição, de constituição de reservas, regulação de sinistros, etc.

Um exemplo do resultado desse tipo de cooperação no Brasil foi o desenvolvimento de coberturas relativas a responsabilidade civil profissional. Caberia aqui, contudo, uma crítica ao monopólio brasileiro da atividade, na medida em que essa possibilidade de troca e diálogo fica restrita a uma única instituição resseguradora. 
Por fim, a função financeira (surplus relief) do resseguro destina-se a aumentar o patrimônio líquido das empresas seguradoras ou melhorar seus índices de desempenho, como a margem de solvência (patrimônio/prêmio) ou índice ativos/responsabilidades.

A necessidade do resseguro para atender a esta função será, contudo, mais ou menos premente dependendo das normas contábeis aplicadas às atividades seguradoras no país em questão. Segundo Botti $^{21}$, no Brasil ela não se aplica integralmente devido à forma de contabilização utilizada hoje nas seguradoras nacionais.

${ }^{21}$ Ibid. pág. 39 


\section{Tipologia do Resseguro}

O resseguro ao longo de sua evolução foi gradualmente ganhando aspectos técnicos e formas de contratação distintos em função das necessidades e aprimoramentos do seguro direto.

Nesse capítulo será abordado o resseguro tradicional sob a ótica das técnicas utilizadas e formas de contratação, bem como, de maneira sintética, o novo tipo de resseguro, o financeiro.

\subsection{Técnicas de Resseguro}

Atualmente a doutrina divide as modalidades técnicas de resseguro em dois grandes grupos: resseguros proporcionais (ou de risco) e resseguros nãoproporcionais (ou de sinistro).

Os resseguros proporcionais são coberturas "de riscos", na medida em que a cedente transfere a resseguradora uma determinada fração das responsabilidades que assumiu nas apólices que compõem a sua carteira. Neste caso, o ressegurador participa do risco referente a cada apólice cedida, acompanhando a sorte do seu cedente naquilo que ocorrer, caso a caso.

Estes resseguros proporcionais concentram-se sob duas formas diferentes: de quota-parte e de excedentes de responsabilidade.

Os resseguros de quota-parte são aqueles que obrigam a cessão de uma porcentagem fixa e uniforme de todas e de cada uma das apólices emitidas no respectivo ramo. A resseguradora torna-se praticamente sócia da seguradora em uma parte da carteira de um ramo, visto que participa de uma fração do risco de cada operação. É amplamente favorável a resseguradora, na medida que recebe 
participação igual dos riscos bons e dos ruins, não podendo a cedente aplicar nenhum critério de seleção.

Nos resseguros de excedentes, transfere-se parte das responsabilidades assumidas, não em todas apólices, apenas nas apólices e nas quantidades que a cedente decidir. Cada caso se baseia em um valor que a cia cedente resolve reter em cada operação e cede-se o excedente até o total da importância segurada, do que resulta uma porcentagem variável em cada apólice.

Nestes dois tipos de resseguros proporcionais ou de riscos, a seguradora deve ceder a resseguradora ou resseguradoras, a mesma proporção do prêmio da apólice como porcentagem da importância segurada cedida. $\mathrm{O}$ ressegurador irá igualmente em cada sinistro participar na mesma proporção em que o risco foi cedido.

O segundo grupo quanto às técnicas de resseguro é chamado de resseguros não proporcionais (ou de sinistros). Nesse a companhia cedente e a resseguradora estipulam a forma como compartilharão os sinistros, sem nenhuma relação com o compartilhamento dos prêmios originais. A característica básica é a proteção da cedente ao invés de uma sociedade entre ela e o ressegurador.

Os resseguros não proporcionais são constituídos basicamente de cinco tipos de coberturas: Excesso de Danos por Risco (Working Cover), Excesso de Danos por Evento, Excesso de Danos por Catástrofe, Limitação da Sinistralidade (Stop Loss) por Ramo e Limitação Global de Sinistralidade por Exercício.

O resseguro com cobertura Excesso de Danos por Risco, também denominado Cobertura de Trabalho, constitui uma forma disfarçada de resseguro de excedentes, pois cobre os sinistros pagos a mais do que o valor denominado Prioridade. Quando a Prioridade ${ }^{22}$ for um valor abaixo da média das importâncias

\footnotetext{
${ }^{22}$ Prioridade é o limite estabelecido do tipo de resseguro Excesso de Danos, até o qual não haverá recuperação de resseguro, é o mesmo que limite de sinistro.
} 
seguradas na carteira de um ramo, esse resseguro começa a funcionar em quase todos os sinistros, como uma cobertura de excedentes com um pleno médio, sem requerer uma perda elevada, nem uma acumulação de apólices, afetadas simultaneamente por um mesmo fato.

Os resseguros não proporcionais com cobertura Excesso de Danos por Evento ou por Catástrofe apresentam relevantes diferenças em relação à cobertura anterior. No primeiro caso, Excesso de Danos por Evento, é de fato necessário que dois ou mais riscos físicos isolados sejam afetados para que comece a vigorar a proteção, tendo em vista que se estabelece uma prioridade a um nível tal que devem ser afetadas várias apólices de valor médio simultaneamente para que se caracterize a responsabilidade do ressegurador. Na cobertura de Excesso de Danos por Catástrofes, o requisito da acumulação tem caráter contratual expresso e, além disso, a prioridade é fixada num valor tal que necessariamente devam estar afetadas muitos riscos por um mesmo fato para que se aplique a cobertura.

O resseguro não proporcional denominado Limitação da Sinistralidade por Ramo (Stop Loss), é uma cobertura de resultados anuais, sendo acionada quando a sinistralidade de um ramo superar uma determinada porcentagem de prêmios recebidos pela companhia cedente.

O quinto tipo de modalidade técnica dos resseguros não proporcionais, isto é, o resseguro de Limitação Global de Sinistralidade por Exercício, é uma cobertura semelhante a anterior descrita, porém em lugar de proteger o resultado da conta de sinistros de um só ramo, considera a sinistralidade consolidada total da companhia seguradora no seu conjunto, consoante expressa na sua Demonstração de Lucros e Perdas. 


\subsection{Formas de Contratação}

Existem duas formas básicas de estabelecer a relação contratual, através da qual se concretiza a relação jurídica entre o segurador e o seu ressegurador:

i) O contrato individual, denominado resseguro facultativo, específico, pelo qual é ressegurada uma determinada operação, um determinado risco no sentido material;

ii) O contrato geral, denominado tratado de resseguro, no qual se estabelecem, para um prazo no mínimo anual, forma, condições, valores e circunstâncias sob as quais ambas as partes combinam ressegurar a parte proporcional das operações ou a parte dos sinistros, que afetem determinado ramo da carteira do segurador.

O resseguro facultativo é utilizado para ressegurar uma operação individual, que fica fora das condições, limites ou características daquelas compreendidas em um contrato geral, existente ou não, porque a seguradora, neste caso particular, não deseja assumir o risco por inteiro. As partes aqui possuem interira liberdade para decidri sobre o oferecimento e aceitação de responsabilidades.

A característica fundamental dessa forma operacional é que a cedente não conta com a cobertura do resseguro até o ressegurador tenha aprovado a operação expressamente. Esta circunstância aponta claramente o inconveniente que resulta do ponto de vista comercial e de custos de administração para realizar a operação.

Por isso, o resseguro facultativo somente é usado para risco especiais, diferenciados, que envolvam individualmente um valor grande do prêmio e uma margem que viabilize os custos de uma análise específica.

Nas operações de tratados de resseguro são feitos acordos entre a seguradora e uma ou mais resseguradoras, nos quais se estabelece previamente os compromissos e condições. À cedentes cabe ceder todos os resseguros dos tipos e 
riscos e à resseguradora cabe aceitá-los, conforme descritos no tratado. Essa operação permite uma automática proteção à companhia cedente, que pode dar cobertura imediata a qualquer proposta cujo risco esteja dentro do escopo do tratado.

Paulo Botti trata do assunto, salientando que:

"O ressegurador operando em tratados deve, antes de aceitá-los, analisar a companhia cedente, seus métodos de aceitação de riscos, sua experiência e resultados e a capacitação de sua administração, em vez de analisar cada risco, como no seguro facultativo. Daí a importância do ressegurador conhecer o mercado onde está atuando, estar inserido nele, ter contato pessoal com a administração das companhias cedentes. Esse contato passa a ser mais importante que o conhecimento individual dos riscos sendo ressegurados, pois o ponto importante dos tratados é a confiança que o ressegurador precisa ter na boa-fé e na competência técnica e administrativa da companhia cedente. Na realidade, o ressegurador faz a "aceitação" da companhia seguradora quando assina um contrato.

A confecção periódica de um bordereaux de resseguro, listando risco a risco os seguros com resseguro para a informação do ressegurador, está praticamente abolida. No Brasil esta prática ainda existe, devido à característica monopolista do resseguro, em que o ressegurador tem de aceitar a cedente e o tratado, e precisa para isso vigiar, conferir e controlar seus dados em detalhes.",23

\subsection{Resseguro Financeiro}

Também chamado de resseguro não tradicional, ou alternativo, o resseguro financeiro pode ser descrito como um contrato no qual a companhia cedente efetivamente realiza um depósito a prazo junto a resseguradora como investimento, ou toma emprestado fundos da resseguradora para financiar o pagamento dos sinistros.

Acerca desse tipo de resseguro paira uma grande controvérsia em função da impossibilidade de se caracterizar o risco da maneira em que é concebido na atividade securitária como um todo. Do ponto de vista legal, um dos principais óbices para chegar uma configuração jurídica do resseguro financeiro é que algumas de suas modalidades não incluem a assunção pelo ressegurador do risco de subscrição, mas tão somente, de riscos puramente financeiros.

Nesse sentido, Sérgio Ruy Barroso de Mello afirma:

${ }^{23}$ Ibid. pág 49 
"É risco também a possível perda do valor das reservas mantidas por anos num contexto econômico determinado, ou a falta de capital integralizado, aspectos que o ressegurador pode paliar, justo por sua natureza internacional de grande profissionalização"’. 24

A natureza jurídica do resseguro financeiro puro dependerá basicamente da natureza jurídica da relação que se estabeleceu entre o cedente e ressegurador, podendo variar entre a administração de portfólios até a concessão de créditos, passando pelo simples depósito, e misturando, por mais das vezes, mais de um destes elementos. Obviamente, quando se tratar de formas mistas de resseguro, será possível identificar em parte da transação algo que seja efetivamente uma operação de resseguro tradicional, cuja natureza jurídica será analisada no próximo capítulo.

Os contratos de resseguro financeiro podem ter por escopo o financiamento de sinistros, melhoria da margem de solvência, proteção contra o crescimento das reservas de sinistros, proteção contra acúmulo de retenções, e a proteção para a companhia seguradora quando deixa de operar um determinado ramo ou classe de negócios, e quando encerra ou transfere sua operação como tal.

O Financiamento de sinistros é atingido, principalmente, através do contrato de excesso de danos agregado prospectivo (ou spread loss), elaborado especificamente para esse objetivo.

A melhoria da margem de solvência permite à companhia cedente expandirse posteriormente, possibilitando que seja de fato ampliada sua capacidade de underwriting. Tal resultado é obtido diretamente com a utilização do contrato financeiro proporcional.

Pela proteção contra o crescimento das reservas de sinistros permite-se à cedente reduzir sua exposição dos sinistros não liquidados, despesas de liquidação e ainda reservas de sinistros ocorridos mas não avisados.

Na proteção contra acúmulo de retenções o objetivo é prover à companhia

\footnotetext{
${ }^{24}$ MELLO, Sérgio Ruy Barroso de.Resseguro: Reflexos Jurídicos da Evolução Contratual. Revista do IRB. .$n^{\circ}$ 284. Rio de Janeiro: abr/jun 2001. p. 46 e 47.
} 
seguradora uma proteção contra acúmulo de retenções, salvaguardando seu próprio lucro.

Através da proteção para a seguradora quando esta deixa de operar em um determinado ramo ou classe de negócios, ou quando encerra ou transfere sua operação de seguradora, é possível transferir a uma resseguradora financeira a gestão dos sinistros pendentes.

Os resseguros financeiros, sob a natureza de seus respectivos objetivos, podem ser divididos em prospectivos e retrospectivos. Serão considerados prospectivos caso sejam relativos a prêmios e riscos futuros, ainda que já subscritos. Ao contrário, se estiverem relacionados a atividades pretéritas da companhia cedente, ou seja, estiverem relacionados cumulativamente a riscos já subscritos e sinistros já ocorridos, estarão na categoria dos retrospectivos.

São essas as principais características do resseguro financeiro que se mostram apropriadas ao objeto do presente trabalho. Há de se notar que embora seja um novo tipo de resseguro, o resultado que se visa obter nas operações de resseguro financeiro é por demais tradicional, qual seja, o de "otimizar o grau de certeza e tranqüilidade nos resultados dos negócios, com máxima eficiência possível, para benefício das seguradoras que, se cuidam de seu capital, beneficiarão finalmente a seus segurados." 25

${ }^{25}$ Ibid. pág 47 


\section{Direito do Resseguro}

Após conceituarmos resseguro e tecermos considerações acerca de suas funções e tipologia, passaremos agora a tratar dos aspectos jurídicos atinentes ao mesmo.

\subsection{Natureza Jurídica do Resseguro}

A atual doutrina, bem como a jurisprudência e legislações, estas quando existentes dispositivos acerca da matéria, são unânimes em afirmar a natureza seguradora do contrato de resseguro, tido, nas palavras de Ariel Dirube, como "um verdadeiro contrato de segundo grau" 26 .

Nessa linha, o Código Comercial alemão define resseguro no seu art. 779, parágrafo $1^{\mathrm{o}}$ : “O resseguro é o seguro do risco assumido pelo segurador." ${ }^{, 27}$ e na Espanha, a natureza jurídica seguradora do resseguro encontra-se positivada nos artigos 77 a 79 da Lei 50/1980, relativa a Contratos de Seguro, como um seguro de dano.

A doutrina pátria também segue esse entendimento, devidamente elucidado por Paulo Piza:

\footnotetext{
"A função econômica-social do resseguro, como negocio jurídico, portanto, é conferir estabilização técnica e financeira às empresas de seguros, livrando-as dos efeitos patrimoniais adversos da ocorrência de múltiplos fatores de desvios e desequilíbrios atuariais a que está irremediavelmente sujeito o exercício da atividade securitária. $\mathbf{O}$ resseguro, portanto, verte-se a garantir um interesse, que é um interesse tipicamente de um segurador: o de conferir essa estabilização, sem a qual o patrimônio que gere, a fim de prestar serviços securitários e, em ultima instancia, o seu próprio patrimônio (se quisermos considera-los patrimônios separados), não serão capazes de responder às obrigações derivadas do exercício da atividade securitária" ${ }^{28}$ (grifo nosso)
}

\footnotetext{
${ }^{26}$ DIRUBE, Ariel Fernández. Manual de Resseguros. São Paulo: General Cologne Re, 1991p. 21.

${ }^{27}$ SWISS REINSURANCE COMPANY. O resseguro dos ramos elementares. $2^{\mathrm{a}}$ ed. Suíça: 1997.

${ }^{28}$ PIZA, Paulo.Seguros: uma questão atual.p.180
} 
A qualificação jurídica do resseguro como um contrato de seguro dá-se em função da resseguradora obrigar-se, mediante a paga de um prêmio, a proteger o patrimônio da cedente frente ao risco substanciado na responsabilidade desta perante seu segurado. Possui, pois, o contrato de resseguro os elementos próprios do contrato de seguro: o interesse, o risco, importância segurada e prêmio.

Nesse sentido, entende-se que surge entre o segurador e ressegurador um acordo que reúne os elementos do contrato de seguro, quais sejam, o risco, um premio e uma prestação pecuniária relacionada a um risco, que, por sua vez, é um evento incerto.

O objeto material do contrato de resseguro é o interesse do segurador em preservar seu patrimônio. $\mathrm{O}$ interesse segurável é formado pela relação entre a companhia seguradora e seu patrimônio, que corre o risco de ser diminuído pela aparição de um passivo contingente, por sua vez, advindo da realização de um pagamento no cumprimento da obrigação contratual assecuratória de indenizar um sinistro, gerado por fato aleatório.

O risco constitui-se pela iminência de que seja materializada a obrigação de pagamento de um sinistro nas condições previamente acordadas.

A importância segurada é a importância ressegurada visto que é dimensionado em todo contrato um valor até o qual a resseguradora se obriga.

O prêmio poderá ser uma fração do prêmio direto cobrado pela cedente, ou outro valor apurado em função de distintos fatores, como no caso dos resseguros não-proporcionais.

Finalmente os sujeitos da relação jurídica contratual, a cedente como segurada e a resseguradora como seguradora.

Ao resseguro assim analisado atribui-se, por muitas vezes, a qualidade de seguro do segurador, independentemente do contrato de seguro celebrado entre a seguradora direta e seu segurado. 


\subsection{Resseguro como seguro de dano}

Assentado o resseguro como um contrato de seguro de segundo grau, a discussão se coloca com relação à classe ou modalidade de que se trata.

No que concerne à natureza securitária do contrato de resseguro, alguns doutrinadores afirmam ser o resseguro uma classe de seguro de responsabilidade civil cujo objetivo é proteger o patrimônio do segurador. Tal teoria é muito criticada dado que, em geral, o acionamento de um seguro de responsabilidade civil pressupõe uma ação ou omissão culposa, enquanto que o valor desembolsado pela seguradora na ocorrência de sinistro representa tão somente o cumprimento de uma obrigação contratual.

Não constitui o resseguro, como se pretende, uma cobertura da responsabilidade civil contratual da cedente em função de violação ou descumprimento de obrigação contratual. Ariel Fernández Dirube trata do tema dizendo:

"Não é a penalidade conseqüente de uma omissão, uma incapacidade, uma imprudência ou uma negligencia (como seria no caso de responsabilidade civil), mas simplesmente a cobertura de uma dívida aleatória, quando a mesma alcançar uma importância determinada ou causar um desequilíbrio no sistema administrado do segurador original, desde que essa dívida tenha uma origem enquadrada na garantia outorgada., ${ }^{29}$

Da mesma forma, Barroso de Mello aduz: "Não é admissível definir o resseguro como um seguro que cobre o segurador-ressegurado 'contra' ou 'por' sua responsabilidade civil, quando esse não atua em descumprimento de suas obrigações". 30

Ainda que a dívida patrimonial decorresse da obrigação de pagamento da seguradora de atos ou omissões culposas do segurado, o que repercutiria somente no

\footnotetext{
${ }^{29}$ DIRUBE, Ariel. Op. Cit. p 23

${ }^{30}$ Sergio Ruy Barroso . 2000. pág 29. Resseguro: Reflexos Jurídicos da evolução contratual. Revista Brasileira de Direito de Seguros, $n^{\circ}$ 9, pág. 27-30, maio/ago.2000
} 
resseguro de seguros de responsabilidade civil, há apenas o vínculo econômico indireto e não jurídico entre o comportamento culposo do segurado e a obrigação do ressegurador, o que em hipótese alguma daria ao resseguro a natureza de um seguro de responsabilidade civil.

Quanto às demais modalidades de seguro, como incêndio, automóvel, transporte, etc., não há que se falar em responsabilidade civil do segurado, tampouco da companhia seguradora.

Outra por parte da doutrina segue a idéia da "identidade do risco". Propõe esta teoria que o resseguro se assemelharia ao mesmo ramo do risco segurado original, ou seja, propõe que o contrato de seguro e de resseguro cobririam o mesmo risco.

A tese em questão se depara com alguns obstáculos, sendo o de maior repercussão na doutrina o entendimento de que a obrigação da resseguradora seria acessória a da seguradora-ressegurada, por ser o risco segurado e ressegurado o mesmo. O resseguro, em última análise, haveria de ser encarado como uma garantia para o segurado, e não um instrumento de uso da seguradora para tutela do interesse de que lhe é próprio.

Além da caracterização do contrato de resseguro como um contrato acessório ao de seguro, equiparado ao de fiança, tal teoria pauta-se na idéia de que o resseguro seria um contrato coligado ao contrato de seguro, ou então um contrato dependente ou subordinado a este. Não mostra ser esta a realidade, pois, como visto, o contrato de resseguro resulta estranho ao segurado, que dele não participa direta e nem indiretamente, não é parte, tão pouco interveniente.

O avanço da técnica ressecuritária evidenciou com precisão a estrutura funcional do negócio, os contratos de seguro, as operações de seguro passaram a ser vistas, unicamente, como pressupostos potencias da conformação do risco objeto do contrato de resseguro. $\mathrm{O}$ risco ao qual está submetida a seguradora é inerente ao exercício de sua atividade empresarial, e só tem o condão de afetar o patrimônio 
administrado pela mesma, não repercutindo na esfera patrimonial deste ou daquele segurado. É, pois, a possibilidade do patrimônio da seguradora ser insuficiente para o adequado desenvolvimento da atividade empresarial.

Logo, se os contratos de seguro representam potenciais fontes de perda, são apenas para a própria seguradora. O contrato de resseguro, por sua vez, volta-se exatamente à garantia do risco de sobrevirem tais pedras, como destaca Sérgio Ruy Barroso de Mello: ${ }^{31}$

"o pagamento pelo segurador das indenizações devidas constitui o que tem se chamado de "dano patrimonial", pelo que tal possibilidade constitui o risco do seguro num Contrato de Resseguro. O interesse segurado no Contrato de Resseguro recai sobre o patrimônio do segurador."

A causa remota da obrigação assumida pela resseguradora é, vale insistir, o incêndio, o roubo, etc., mas não é esse o risco. A resseguradora não garante nem direta ou indiretamente o segurado contra esses eventos, não há relação jurídica. $\mathrm{O}$ risco está configurado na causa última, isto é, a diminuição patrimonial da cedente em virtude da causa remota.

Conclui com muita propriedade Paulo Piza:

"Ora, se o risco é a possibilidade de um evento desvantajoso e incerto para quem contra ele se premune, o risco do segurado e o risco do segurador-ressegurado são distintos, não se confundem. São riscos que derivam de eventos diversos, garantidos em contratos diversos. Logo, não se pode tê-los como coincidentes." ${ }^{32}$

A corrente dominante na doutrina, dessa forma, considera o resseguro um seguro de dano, independentemente do seguro originário, em virtude da obrigação da resseguradora guardar relação com os danos sofridos no patrimônio da seguradora.

Compartilham desse entendimento Ariel Dirube e Vera Helena Helena de Melo Franco, afirmando, respectivamente, que o resseguro:

\footnotetext{
${ }^{31}$ MELLO, Sérgio Ruy Barroso de.Resseguro: Reflexos Jurídicos da Evolução Contratual. Revista do IRB. .$n^{\circ}$ 284. Rio de Janeiro: abr/jun 2001. p. 46 e 47.

${ }^{32}$ Piza Seguros uma questão atual. Pág 183
} 
“(...) é um seguro de danos patrimoniais, porque protege a integridade do patrimônio da cedente, na medida em que este for afetado pelo aparecimento de uma dívida, de um Passivo, constituído pelo valor da indenização que deve ser paga ao seu segurado sinistrado". 33

“(...) cobre as conseqüências patrimoniais para a seguradora, derivadas do cumprimento das obrigações previstas no contrato de seguro, (...) é um contrato de seguro de danos com finalidade de cobrir aquelas responsabilidades perante o segurado. (...) $\mathrm{O}$ risco assumido não é, porem, o risco do contrato original, (...) não há recobertura, mas cobertura de outro risco". 34

Mesmo, na hipótese do risco ressegurado estar relacionado a um seguro pessoal, de quantia certa (na ocorrência de sinistro o segurado recebe quantia certa e preestabelecida, seja ela compatível ou não com a perda efetivamente sofrida) ou de dano (baseado na teoria da necessidade concreta, isto é, visa a recuperação do patrimônio efetivamente lesado), o resseguro deve ser considerado seguro de dano, pois não pode a companhia resseguradora pagar a cedente quantia desvinculada da lesão sofrida em seu patrimônio sob pena de enriquecimento sem causa.

Cumpre advertir, porém, a necessidade de que o advento da dívida deva constituir realmente um sinistro, ou seja, um fato acidental perfeitamente enquadrado na cobertura da apólice original, que obrigue juridicamente a seguradora a indenizar o segurado. Isso porque nem toda reclamação do segurado constitui realmente sinistro, ao passo que todo sinistro corretamente configurado e que repercurta no âmbito do contrato de resseguro, obriga a resseguradora a indenizar a cedente.

Em virtude de o resseguro cingir-se ao risco de dano patrimonial da seguradora cedente, é que muitos doutrinadores preferem designá-lo como o seguro do segurador, em lugar de defini-lo como "seguro do seguro".

\footnotetext{
${ }^{33}$ Dirube pág 23

${ }^{34}$ Vera helena pág. 128
} 


\subsection{O contrato de Resseguro}

Demonstrada a natureza seguradora do contrato de resseguro, sem, entretanto, negligenciar-se suas características particulares que o distinguem da estrutura tradicional do seguro, é o resseguro um contrato oneroso, aleatório, consensual, de estrita boa-fé, bilateral e de trato sucessivo.

Oneroso porque visa uma mútua vantagem de caráter econômico, sendo o prêmio, inclusive, elemento fundamental no contrato de resseguro. Aleatório já que a obrigação do ressegurador está condicionada a ocorrência de fato eventual, qual seja, obrigação do pagamento por um sinistro a cargo da cedente, decorrente de uma circunstancia fortuita, incerta em si mesma ou incerta quanto ao momento de ocorrer.

Consensual, pois seu aperfeiçoamento depende unicamente do consentimento de ambas as partes, ainda que exija uma prova escrita para demonstrar suas condições. É bilateral por gerar obrigações recíprocas diferenciadas, e, de estrita boa-fé posto que as decisões da resseguradora são baseadas nas informações da cedente.

É de execução continuada ou trato sucessivo, isto é, não reconhece um só momento da execução, a proteção outorgada ocorre de forma ininterrupta cumprindo seus efeitos durante toda a vigência compactuada.

Quanto à tipificação do contrato de resseguro Marcelo Haddad assevera:

“(...) torna-se difícil enquadrá-lo como um contrato tipificado em função do fato de que a atividade resseguradora está menos sujeita ao dirigismo estatal e que nem todas as legislações nacionais optaram por regulá-lo expressamente, pelo que preferimos não incluir tal menção no rol de qualificativos que caracterizam juridicamente o contrato de resseguro". 35

Não se trata também de um contrato de adesão, tal qual o seguro em geral, competindo às partes a proposição de condições, modificação ou discussão das cláusulas contratuais. Tampouco há modelos de contrato de resseguro com

\footnotetext{
${ }^{35}$ obra citada pág. 54
} 
condições gerais previamente estabelecidas e aprovadas administrativamente. Tratase de contrato realizado entre dois profissionais - duas pessoas jurídicas igualmente instruídas - em comunhão de interesses econômicos, prescindindo, assim, de uma intervenção estatal como nos contratos de adesão.

Dessa autonomia das partes na determinação do objetivo dos contratos advém a multiplicidade de formas e técnicas de resseguro delineadas pela prática.

Por fim, uma peculiaridade a distinguir o contrato de resseguro do seguro, especialmente a nível internacional, surge da estreita comunhão de interesses, pois se realiza um trabalho conjunto baseado na completa confiança entre seguradora e resseguradora de forma que, embora caiba a seguradora a administração das carteiras de riscos ressegurados, a companhia resseguradora normalmente atua como conselheira técnica, aportando ao negócio experiência e conhecimento para benefício de ambas.

\subsection{Princípios aplicáveis ao Resseguro}

A cargo do caráter internacional do resseguro, este instituto, na maioria dos países, não recebe tratamento legislativo especifico, quando muito os ordenamentos nacionais limitam-se a estabelecer que não são aplicáveis a ele as regras relativas ao contrato de seguro.

Em virtude dessa escassez de regras nacionais materiais tratando especificamente do resseguro, os costumes do mercado ressegurador internacional e os próprios contratos revelaram-se grandes fontes de direito ressecuritário. $\mathrm{O}$ uso da arbitragem na solução de controvérsias, que embora não seja caracterizada como costume por não possuir caráter obrigatório, integra a praxe ressecuritária juntamente com os princípios securitários nacionais aplicáveis ao resseguro.

No que diz respeito aos dispositivos nacionais aplicáveis ao resseguro, Marcelo Haddad $^{36}$ divide os países que possuem alguma regulamentação sobre o

\footnotetext{
${ }^{36}$ Marcelo Haddad. O resseguro Internacional pág 58
} 
assunto em basicamente em três grupos, podendo alguns países, inclusive, se enquadrarem em mais de um:

i) os que regulam o resseguro de forma negativa, excluindo a aplicação das regras securitárias ao mesmo, como Alemanha, Suíça, Franca, Suécia, Áustria, Dinamarca, Noruega e Finlândia;

ii) aqueles cujas legislações comerciais permitem que riscos segurados sejam ressegurados junto a outro agente econômico, tais como, Alemanha, Áustria, Inglaterra, França, Inglaterra, Argentina, Venezuela, Holanda, Bélgica;

Brasil;

iii) aqueles cujas legislações trazem poucas regras relativas especificamente a atividade resseguradora, em geral regulando a relação entre segurador e ressegurador, bem como a inexistência de relação jurídica com o segurado, Itália, Franca, Espanha, Brasil, Inglaterra, Argentina, Colômbia, Estados Unidos da América (Nova Iorque, Califórnia).

Independentemente dessa classificação, e ainda que as normas securitárias não se apliquem a atividade resseguradora, a atividade ressecuritária é regida não só por seus princípios internacionais, como por certos princípios nacionais orientadores da atividade securitária. Os de maior relevo são os princípio da boa-fé e da comunhão de sorte.

\subsubsection{A Máxima Boa-fé}

Não obstante o contrato de seguro estar, como todo negócio jurídico, sujeito ao principio jurídico da boa-fé, vários ordenamentos nacionais (Inglaterra e Argentina, por exemplo), ao tratarem das normas securitárias acentuam a relevância deste principio, referindo-se ao mesmo como princípio da máxima boa-fé ou da mais estrita boa-fé.

No que tange ao direito securitário brasileiro, o legislador foi claro ao estabelecer no artigo 765 do novo Código Civil (art. 1.443 CC/1916) que as partes 
no contrato de seguro, segurador e segurado, são obrigados a guardar a mais estrita boa-fé e veracidade em todas as fases do mesmo, tanto no que se refere ao seu objeto quanto às circunstancias e declarações a ele pertinentes.

A exigência se faz necessária, principalmente, uma vez que as decisões negociais da seguradora baseiam-se nas declarações dos segurados. A par dos meios de investigação e controle das companhias seguradoras, a veracidade das informações fornecidas pelo segurado sobre o interesse segurável e os riscos contra os quais se quer proteger é indispensável para a aceitação da cobertura securitária e determinação do valor do prêmio. O seguro sem essa base de confiança seria impraticável.

Nesse sentido, Pedro Alvim afirma que a boa-fé "não constitui um privilégio do contrato de seguro, mas é aí reclamada com maior insistência, dada relevância de que se reveste na formação e execução do negócio"37

Mais do que simplesmente dever de informar, a conduta das partes com relação à outra deve estar pautada em consonância aos preceitos da boa-fé, entendidos por honestidade, lealdade, integridade e transparência.

Analisado de um lado o instituto do resseguro no âmbito da estrita vinculação jurídica entre a resseguradora e as partes intervenientes na relação securitária, e de outro, as razões que levam o princípio da boa-fé a sobressair-se nesta última, não há como esquivar-se da conclusão de que o contrato de resseguro, a relação contratual entre seguradora e resseguradora, está, da mesma forma ou ainda mais intensamente, regida por tal principio.

Por força da própria estrutura da atividade ressecuritária, formada a partir dos costumes internacionais, dá-se à seguradora, salvo raras exceções, completa liberdade na administração e aceitação de riscos, restando à companhia resseguradora depositar absoluta confiança na cedente. Melhor, como a resseguradora, em regra geral, apenas tem acesso a informações esparsas sobre cada risco da carteira de seguros ressegurada da cedente, é indispensável que haja 
confiança nas atividades negociais desenvolvidas por esta, a qual caberá a máxima diligência, como se seu risco não estivesse ressegurado.

Cuidando-se o resseguro de um contrato de seguro, o princípio da mais estrita boa-fé retoma sua "acepção original e pura" ${ }^{38}$, a ser observado pela cedente face a sua resseguradora.

A relevância da atenção a esse princípio se manifesta, sobretudo, quando da interpretação dos contratos de resseguro e na conduta das partes. Nesse primeiro momento é que o princípio da máxima boa-fé se mostra primordial, pois o intérprete, na análise das cláusulas, em especial frente ao um conflito de interpretação, presumir-se-á a idoneidade das intenções e os objetivos iniciais dos contratantes. Ou seja, na análise das cláusulas contratuais deverão ser descartadas leituras retorcidas e ambivalentes que somente estariam na intenção de um contratante despojado de boa-fé.

$\mathrm{Na}$ execução do contrato, a máxima boa-fé também deverá pautar as condutas das partes, dada a presunção do perfeito conhecimento das práticas internacionalmente aceitas e aplicáveis ao contrato, contra as quais não sendo nada estipulado em contrario, é porque de boa-fé, as mesmas as têm julgado aplicáveis a sua relação particular.

À cedente cumpre transparência e clareza em sua atividade, e uma atuação como se ressegurada não fosse, no intuito de que a resseguradora não venha a suportar conseqüências mais negativas do que seriam suportáveis para si em caso não houvesse resseguro.

Ademais, a boa-fé, além de princípio, é uma obrigação positiva no contrato de resseguro, posto que muitos contratos incorporam, já no enunciado, a obrigação de atuar-se com a mesma, e quando não expressa, os usos e costumes sempre enunciados nos contratos como aplicação impositiva de seu tramite, determinam a vigência desse princípio.

\footnotetext{
${ }^{38}$ Marcelo Haddad pág. 62
} 


\subsubsection{O Dever de Informação}

O dever de informar surge como conseqüência natural do princípio da máxima boa-fé. Preceito basilar das relações securitárias, o dever de informar abarca o dever pré-contratual e contratual do segurado de prover a seguradora de todas as informações relativas ao risco a ser assumido, bem como as circunstâncias capazes de agravá-lo, além, é claro, do dever de comunicação quando da ocorrência de sinistro.

Como bem lembrado por Vera Helena de Mello Franco ao tratar da relevante idoneidade nas informações prestadas pelo segurado:

“o prêmio é calculado em razão do risco avaliado e é do conjunto de prêmios (fundo comum) que a seguradora retira as indenizações que deverão ser pagas. Portanto, quando o segurado falseia suas declarações altera o equilíbrio da mutualidade, já que paga menos por riscos superiores" ${ }^{39}$

Nesse sentido, o novo Código Civil estabelece no art. 766 sanções para o caso de declaração ou omissão dolosa passível de influir na aceitação da proposta ou na preço do prêmio, como também na hipótese da inexatidão ou omissão não resultar de má-fé do segurado.

Se a companhia resseguradora participa indiretamente do risco segurado, posto que inexiste vínculo direto entre segurado e resseguradora, deverá tal princípio ser aplicado analogicamente na relação ressecuritária, ou seja, na relação entre seguradora e resseguradora.

À seguradora caberá a obrigatória transmissão das informações sobre o risco ressegurado, sua extensão e natureza, como também sobre determinado contrato de seguro capaz de influenciar nas técnicas securitárias de valoração.

\subsubsection{A Proibição Relativa ao Locupletamento llícito}

\footnotetext{
${ }^{39}$ Mello Franco. 1993. P. 49.
} 
Regra geral do direito civil, a proibição do locupletamento ilícito, uma variação do princípio que veda o enriquecimento ilícito, aplica-se especificamente à contratação de seguro, em especial, ao seguro de dano.

Dessa forma, o Código Civil brasileiro, em seus arts. 778 e 781, determina que a garantia prometida em contrato não poderá ultrapassar o valor do interesse segurado no momento da conclusão do contrato, tampouco poderá a indenização ultrapassar o valor do interesse segurado no momento do sinistro.

Pedro Alvim discorrendo sobre a importância segurada nos seguros de dano, afirma:

"Se o bem é representado por seu valor no contrato, o segurado não pode pretender receber, em caso de ocorrência do risco, quantia superior. Obteria um lucro além da indenização de seus prejuízos. O seguro não constitui fonte de renda, mas apenas garantia e segurança. Não é uma operação de jogo ou aposta, mas de previdência." 40

Destarte, sendo o resseguro um seguro de dano, aplicar-se-á igualmente a ele o princípio que veda o enriquecimento sem causa do segurado, que na relação ressecuritária é a seguradora, sob pena violar-se frontalmente o caráter indenizatório de suas prestações securitárias.

\subsubsection{Comunhão de Sorte}

Conhecido como follow the fortune, esse princípio internacional do resseguro traduz-se na necessária repercussão, ainda que parcial, das conseqüências advindas da atividade securitária no patrimônio da comanhia resseguradora. Nas palavras de Ariel Dirube:

"O principio da comunidade de sorte significa que o ressegurador enfrenta ou beneficia-se das continências negativas ou positivas que afetem o segurador direto, mesmo se este as tiver provocado voluntariamente, desde que tenha atuado sem ma-fe, ou seja, sem dolo ou culpa grave"

\footnotetext{
${ }^{40}$ Alvim. 1999. P. 303.

${ }^{41}$ Dirube pág 25
} 
Verifica-se a incidência desse princípio, em particular, na ocorrência de sinistro, pois a resseguradora irá acompanhar as decisões da cedente no que lhe cabe no pagamento de sinistro, isto é, o acompanhamento da sorte significa que a ocorrência de um sinistro obriga nas suas proporções e no âmbito de suas responsabilidades a seguradora e, em segundo plano, a resseguradora .

A resseguradora, em conformidade com mesmo, está sujeita às mesmas circunstancias que afetam a relação jurídica entre seguradora e segurado, isto é, às circunstâncias externas geradas sem qualquer interferência da cedente, desde que estejam assumidas no âmbito do contrato e não decorram da atividade empresarial da cedente.

A abrangência do termo follow the fortune restringe-se tão somente a sorte securitária, e não a sorte empresarial, excluindo-se da regra qualquer risco de crédito relativo ao prêmio pago pelos segurados, cuja inadimplência não eximirá a seguradora de suas obrigações para com a resseguradora. Prevalecerá o prêmio recebido pela resseguradora ainda que a cedente, após ter recebido o original, venha a perdê-lo em virtude de fraude de agente ou empregado ou de um banco, pois os contratos são juridicamente independentes entre si.

Christoph Pfeiffer ao discorrer sobre o assunto acrescenta:

\begin{abstract}
"Tampouco pode-se inferir do principio do acompanhamento da sorte que o ressegurador tenha que fazer pagamentos que vão alem do limite de responsabilidade previsto no contrato ou que tenha que cobrir sinistros de seguros que, de acordo com o contrato, não recaem na categoria de risco ressegurado"42
\end{abstract}

Não é uma outorga de carta branca a cedente, mas sim a responsabilização da resseguradora por tudo aquilo que for feito dentro do âmbito contratual e na boa prática do negocio, como, por exemplo, os custos e despesas incorridos na liquidação de um sinistro.

\footnotetext{
42 pág 31 Pfeiffer, Christoph. Introdução ao Resseguro: O manual para teoria e pratica. $4^{\mathrm{a}}$ Ed. Revista e atualizada.1994. Gabler Editora. Grupo Bertelsmann International
} 
Destaca-se, nesse ínterim, a cláusula de erros e omissões, que determina que erros e omissões involuntários da cedente na execução na execução de contrato não invalidam a cobertura de resseguro, devendo, contudo a mesma comunicar de imediato os erros descobertos.

Em um contrato obrigatório, como ocorre no Brasil em virtude do monopólio, caso a cedente esqueça de incluir um risco em seu borderaux ou se equivoque, será a resseguradora responsável apesar disso, até o montante da sua obrigação contratual de prestação, reservando-se, contudo, à resseguradora o direito de inspecionar os livros da cedente e documentos relativos ao contrato de resseguro.

Exceção feita ao resseguro financeiro, o follow the fortune aplicar-se-á indistintamente a todos os tipos de contrato de resseguro, variando apenas a forma na qual a resseguradora irá compartilhar da sorte da cedente. Lembrando-se, contudo, que nos contratos não-proporcionais, em regra geral, a obrigação da resseguradora só é acionada após os sinistros atingirem certo montante, e, por isso, os resultados técnicos da cedente e da resseguradora não são normalmente idênticos. Já os proporcionais aproximam-se ao conceito puro de comunhão de sorte.

\subsection{Ilegitimidade do Segurado frente ao Ressegurador}

A idéia freqüente de que a companhia resseguradora responde diretamente ante o segurado, sem prévia e devida análise dos pressupostos contratuais e os exatos limites de suas cláusulas, contrapõe-se aos princípios já enraizados de interpretação dos contratos de seguro e resseguro, ameaçando, inclusive, a própria capacidade da resseguradora em administrar e garantir as coberturas contratadas, face ao impacto potencial no controle de suas perdas.

$\mathrm{Na}$ breve análise que se segue, será possível constatar que da independência entre os contratos de seguro e resseguro surgem suficientes conceitos doutrinários dos pressupostos de formação da relação jurídica entre as partes, capazes de afastar a 
idéia de legitimidade contratual, e a concluir-se que a intervenção da resseguradora nas demandas é recomendável, mas não obrigatória.

Será, nesse ínterim, apreciada a qualidade da intervenção do IRB no âmbito das ações de seguro.

A Seção V do Decreto-Lei 73/66, ao tratar das liquidações de sinistros, estabelece no caput do artigo 68: “O IRB será considerado litisconsorte necessário nas ações de seguro, sempre que tiver responsabilidade no pedido". Não obstante, o mesmo artigo, em seu $\S 3^{\circ}$ dispõe: “O IRB não responde diretamente perante os segurados pelo montante assumido em resseguro".

Nota-se aqui clara contradição do artigo no que diz respeito ao pedido formulado nas ações de seguro propostas pelos segurados em face das seguradoras, pois se o ressegurador não responde diretamente em nenhum caso perante os segurados pelo montante assumido em resseguro, como poderia vir a ter responsabilidade no pedido.

Com o advento do Código de Processo Civil de 1973 (Lei 5.869, de 11 de janeiro de 1973) determinando o litisconsórcio necessário no art. $47^{43}$, em virtude de lei ou pela natureza jurídica da relação, agravaram-se as dúvidas ao citado art. 68, que embora se refira de maneira expressa ao litisconsórcio necessário, é explicito em dizer que o IRB não responde perante o segurado. Ora, se o IRB não responde pelo segurado não é sensato pensar que o mesmo ao propor ação em face da seguradora, possa reunir no pólo passivo da demanda o IRB.

No que concerne a parte final do artigo 47 do CPC, a questão é se a eficácia da sentença na ação de seguro do segurado em face da seguradora estabelecerá obrigação ou incidirá sobre direito do ressegurador, como terceiro, se cabe extensão da coisa julgada.

\footnotetext{
43 "Há litisconsórcio necessário, quando, por disposição da lei ou pela natureza da relação jurídica, o juiz tiver de decidir a lide de modo uniforme para todas as partes; caso em que a eficácia da sentença dependerá da citação de todos os litisconsortes no processo."
} 
O entendimento jurisprudencial do Superior Tribunal Federal era de que como o IRB não participa do contrato de seguro, imperioso era reconhecer que a sentença condenatória não o alcançaria, limitando-se aos seus contratantes. Negavase, pois, a intervenção do IRB como litisconsorte necessário nas ações de seguro. Entendimento este, predominou no STF nos últimos julgados da matéria, quando da criação do Superior Tribunal de Justiça em 1988.

O STF chegou a concluir que a denunciação da lide seria meio inidôneo para provocar a intervenção do IRB, por inexistir relação material de regresso a consentir ressarcimento imediato de que se pudesse aproveitar a seguradora. Tendo em vista ser a litisdenunciação uma ação regressiva incidental, na qual se formula pedido contra terceiro que deva indenizar, nas hipóteses previstas nos incisos do art. 70 do CPC, nenhuma aplicável a situação do IRB.

Ao IRB, isento de responsabilidade regressiva quanto às obrigações da seguradora perante o segurado, não seria impositivo ingresso na demanda, e impróprio o instituto de denunciação da lide. O seu interesse habitaria tão só o resultado da mesma, à medida que a uma sentença condenatória poderia repercutir sobre o patrimônio da seguradora, deixando-se a seu critério como coadjuvante ou não. Assim, em uma ação de seguro, procedendo a seguradora à denunciação da lide ao IRB, cabia ao juiz adaptá-la à simples cientificação da existência de processo, para que esse, querendo, o recebesse no estado em que se encontrasse, sem qualquer sobrestamento do feito ${ }^{44}$.

Contudo, o STJ, seguindo o entendimento do Ministro Athos Gusmão Carneiro que em seus acórdãos, quando ainda integrava o Tribunal de Justiça do Rio Grande do Sul, posiciona-se de modo diverso. Feita a declaração da seguradora de que tem o IRB responsabilidade por conta do pedido inicial da ação proposta pelo segurado em face da seguradora, cumpre citá-lo a comparecer nos autos como

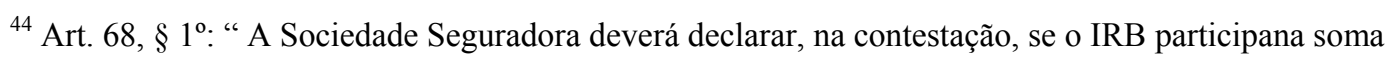
reclamada. Sendo o caso, o juiz mandará citar o Instituto e manterá sobrestado o andamento do feito até a efetivação da medida processual."
} 
litisconsorte necessário. Tal entendimento baseia-se, em síntese, na determinação da lei assentada no caput do artigo 68 do Decreto-Lei 73/66, que estabelece o litisconsórcio sempre que o IRB tiver responsabilidade no pedido.

Recai aqui a discussão sobre a relação de direito material, a fim de que se descubra quando o IRB terá responsabilidade em relação ao pedido formulado pelo segurado em face da seguradora. Se, portanto, os contratos de resseguro e seguro são autônomos, independentes entre si ou se o contrato de resseguro é coligado, acessório ao de seguro.

Elucidando a questão que circunda o risco no contrato de resseguro, já exposta no curso do presente trabalho, Paulo Piza afirma que:

“(...) não transfere o segurador-ressegurado para o ressegurador o risco ou riscos de seus segurados, mas, sim, um risco que lhe é próprio, um risco que pesa unicamente sobre interesse seu, enquanto segurador, um risco, enfim, que não se confunde com o risco ou riscos de seus segurados." 45

A ocorrência de sinistros no universo dos riscos assegurados pela seguradora incidirá no seu próprio risco como tal, ou seja, a possibilidade de se verificar a sua incapacidade técnica de absorver os efeitos daí decorrentes.

Continua o autor:

"O evento passível de caracterizar o sinistro, como risco, no âmbito da relação ressecuritaria, é o atinente ao contrato de resseguro, não o evento ou eventos previstos nos contratos de seguro celebrados pelo segurador- ressegurado. Ora, se o risco é a possibilidade de um evento desvantajoso e incerto para quem contra ele se premune, o risco do segurado e o risco do segurador-ressegurado são distintos, não se confundem. São riscos que deveriam de eventos diversos, garantidos em contratos diversos. Logo, não se pode telos como coincidentes",46

Assim, parece correto o entendimento do STF até 1988 de que não havia possibilidade de identificar relação de direito material entre um segurado e o IRB. Encontra-se a relação ressecuritária num plano diverso da relação securitária, não

\footnotetext{
${ }^{45}$ Piza. Pág 181. Seguros uma quetsão atual.

${ }^{46}$ Pág 183. Livro Seguros uma quetsão atual
} 
respondendo o IRB perante o segurado, tal qual enuncia o $\S 3^{\circ}$ do art. 68 do Decreto-Lei 73/66.

Ainda que coubesse ao IRB a regulação de um sinistro ocorrido na relação securitária, isso não legitimaria a pretensão exercitável de direito material em face do IRB, dado que é uma disposição de ordem contratual, presente só no contrato de resseguro. A regulação de um sinistro de que foi avisado é um autêntico dever da seguradora, e se ela o presta perante o segurado, através de interposta pessoa, isso não significa que a seguradora se exima de responder perante o mesmo pelo descumprimento, do terceiro, desse dever de regular o sinistro.

Melhor, ao segurado pouco importará se é o IRB quem impede a seguradora de pagar a indenização. Trata-se de descumprimento da obrigação da seguradora, e não do IRB. Será a pretensão do segurado exercitável exclusivamente em face da mesma, quer para exigir a regulação do sinistro, quer para contestar conclusão da seguradora pelo não cabimento de indenização.

Não há que falar, pois, em litisconsórcio necessário do ressegurador e da seguradora nas ações de seguro em função da natureza da relação, tampouco por disposição de lei, como usualmente argumenta o STJ, dado que o caput do artigo 68 do Decreto 73/66 condiciona aquela à existência de responsabilidade do órgão ressegurador, o que se pode concluir, pelo exposto, que nunca ocorre. Logo, o IRB ressegurador nunca será litisconsorte necessário nas ações de seguro, não há responsabilidade regressiva, não há porque citá-lo.

A redação do caput do referido artigo contradiz-se e sua aplicação fere uma das principais características inerentes a função própria do ajuste ressecuritário desde o século XIV, que é a exclusiva relação jurídica entre ressegurador e segurador.

Mais apropriado seria a intervenção processual por meio da assistência simples, prevista no caput do art. 50 do CPC: "Pendendo uma causa entre duas ou mais pessoas, o terceiro, que tiver interesse jurídico em que a sentença seja favorável a uma delas, poderá intervir no processo para assisti-la.” 
De fato, a finalidade da assistência do IRB é que uma das partes vença, no caso a seguradora-ressegurada. Nelson Nery Junior ao discorrer sobre a assistência simples ressalta:

"Há interesse jurídico do terceiro quando a relação jurídica da qual seja titular possa ser reflexamente atingida pela sentença que vier a ser proferida entre assistido e a parte contrária. Não há necessidade de o terceiro tenha, efetivamente, relação jurídica com o assistido, ainda que isso ocorra na maioria dos casos."

Afasta-se assim, a idéia da assistência litisconsorcial, (art. 54, do CPC), dado que há o interesse do IRB no resultado da demanda, sem, contudo, ter um direito a propugnar, por não integrar o vínculo que se estabelece entre seguradora e segurado, inexistindo direito seu no litígio daí decorrente.

Ao discorrer sobre o tema, Paulo Piza afirma:

"Estamos diante, ao meu ver, de um caso de assistência simples, porquanto o ressegurador, na dicção do art. 50 do Código de Processo Civil, tem apenas: 'interesse jurídico em que a sentença seja favorável' à seguradora. Desnecessário dizer que esse interesse jurídico não se confunde com o interesse de agir. O interesse jurídico a que se refere o art. 50 do Código de Processo Civil, segundo a doutrina, é identificável em qualquer sityuacao jurídica do terceiro que possa ser indiretamente atingido,de fato, pelos reflexos de uma sentença de mérito." 47

Nelson Nery Junior ao enumerar os requisitos para admissão da assistência litisconsorcial extermina qualquer duvida:

“A sentença atingira diretamente a relação jurídica que o assistente litisconsorcial tem com a parte contrária do assistido. São requisitos para a admissão da assistência litisconsorcial: (...)b) o direito discutido em juízo diga respeito ao assistente; (...) d) haja relação jurídica entre assistente e o adversário do assistido; e) a sentença haja de influir diretamente (e não reflexamente) nessa relação jurídica; (...)

Continua, o autor:

"Ainda que não intervenha no processo como assistente, será inexoravelmente atingido pela sentença, (...)"48

\footnotetext{
${ }^{47}$ Piza. Seguros uma questão atual. Pág 191

${ }^{48}$ Nelson Nery Junior e Rosa Maria Andrade Nery. Código de Processo Civil Comentado e legislação processual civil extravagante em vigor. $4^{a}$ ed. Revista e ampliada. 1999. editora Revista dos Tribunais. Pág 484. Total $3007 \mathrm{p}$.
} 
O mestre Pontes de Miranda ao tratar do interesse jurídico na assistência encerra a questão:

"Há interesses a que não corresponde (ou ainda não corresponde) algum direito. Defende sempre o direito de outrem, a quem assiste. Se o direito defendido é comum, ou se o seu direito ou obrigação deriva do mesmo fato, ou regra jurídica de que deriva direito alheio, ou se há conexão, ou afinidade de questões por ponto comum de fato ou de direito, há litisconsórcio, e não assistência. $\mathrm{O}$ interesse jurídico do assistente não é o que o leva a oporse, ou a litisconsorciar-se. Se algum direito dele é que lhe dá tal interesse, não é esse direito que ele defende, é o da parte assistida, de modo que só até aí é adversário da parte contrária ao assistido. Tem ele interesse jurídico - quer tenha algum direito quer não - em que vença o assistido, mesmo só em parte. Nada pede para si.,"49

Proposta a ação em face da cedente, o ressegurador poderá vir a integrar a lide, nela intervindo como parte interessada, embora seja sempre secundária sua posição, derivante da responsabilidade que for apurada contra a seguradora e apenas a ela respondendo.

Sergio Barroso completa que “(...) essa intervenção, longe de ser por provocação do segurado, o seria pelo chamamento formulado pelo segurador, ou pelo próprio interesse do ressegurador, legitimado pelo contrato de resseguro, a integrar o feito e acompanhá-lo ate o seu final."

Assim, conforme o parágrafo único do art. 50, o IRB, como assistente simples, poderá ingressar a qualquer tempo e grau de jurisdição, bem como em todos tipos de processo.

A questão da legitimidade parece se aproximar de uma preocupação humanitária dos julgadores em favor da vitima, deixando-se de lado por esquecimento ou mesmo por desconhecimento, o exame técnico indispensável ao caso, da tecnicidade inerente a atividade securitária como um todo. Nesse sentido, Barroso de Mello:

"Esse humanitarismo explicar-se-ia se a tendência dos próprios magistrados e demais pessoas fosse ressarcir voluntariamente aos indivíduos por eles lesados, o que não é o caso. Note-se que até a própria vitima muda sua atitude quando é agente de dano. Em virtude dessa volubilidade há de se aferir-se o risco assumido pela resseguradora e o papel

\footnotetext{
${ }^{49}$ Miranda, Pontes de. Comentários ao Código de Processo Civil. Rio de Janeiro. Forense, BRASÍLIA. 19723. Tomo II, $2^{\mathrm{a} e d . ~ P a ́ g . ~} 68$
} 
indenizatório do seguro. O mais social é que pauta o risco, logo, em sua função há de verificar-se o modo de participação da resseguradora."

Ademais, se verificada a função social do contrato de resseguro, temos que o freqüente entendimento em contrário levaria a própria debilidade do sistema securitário. Não é lícito cogitar-se de ações repressivas a constranger o ressegurador a pagar o que não é devido e contratado, logo, não inserido no âmbito das obrigações contratuais. Os reflexos do entendimento podem visivelmente atingir diretamente as reservas constituídas, pondo-se em risco a atividade ressecuritária, e, por conseqüência, a própria atividade securitária.

\section{Resseguro no Brasil e a Perspectiva de Abertura do Mercado}

Como sabido, o Instituto de Resseguro do Brasil, hoje denominado IRB Brasil Resseguros S.A., ainda detém o monopólio da atividade resseguradora no país, atuando, a um só tempo, como única empresa resseguradora e o próprio órgão regulador do mercado de resseguros.

A questão da abertura do mercado ressegurador brasileiro mostra-se latente em função da necessidade do país adequar-se à realidade internacional, não monopolista, inclusive com vista ao MERCOSUL, onde, aliás, as discussões e questionamentos acerca desse monopólio intensificaram-se face à assimetria da legislação nacional a dos signatários do Tratado de Assunção.

\subsection{Proposta Inicial de Abertura do Mercado Ressegurador}

A primeira providência concreta no sentido de abrir o mercado ressegurador, a Emenda Constitucional n ${ }^{\circ}$ 13, de 21 de agosto de 1996, atribuiu nova redação ao art. 192 da Constituição Federal de 1988, excluindo do seu inciso II a expressão 
“órgão oficial ressegurador" ${ }^{50}$, e, portanto, eliminando do ordenamento jurídico a regra especial que garantia o monopólio ao IRB.

Nesse passo, o Instituto de Resseguros do Brasil sofreu uma restruturação por força da Lei $\mathrm{n}^{\circ}$ 9.482, de 13 de agosto de 1997 (Medida Provisória $\mathrm{n}^{\circ}$ 1.578, de 18 de junho), sendo transformado numa forma de sociedade por ações típica. As ações ordinárias foram transferidas para o Tesouro Nacional e as preferenciais para o mercado segurador brasileiro, permanecendo assim, como empresa estatal de economia mista, com controle acionário da União, e redenominada para IRB-Brasil Resseguros S.A. Em dezembro do mesmo ano, o Decreto ${ }^{\circ} 2.423$, incluiu o órgão ressegurador no Programa Nacional de Desestatização (PND).

Em 1999, o Governo Federal sinalizou a quebra do monopólio do resseguro e a privatização do IRB através da Lei $\mathrm{n}^{\circ}$ 9.932, de 20 de dezembro daquele ano, ao transferir a fiscalização e a normatização do setor de resseguro para a SUSEP. No intuito de incentivar a privatização, o Conselho Nacional de Desestatização (CND) decidiu que ao IRB seria feita uma reserva de mercado de 40\% das apólices de resseguros, durante um período de dois anos após a mesma. Assim, teria prioridade na aceitação do resseguro, para, posteriormente, haver a transição definitiva entre o monopólio e o livre mercado.

Entretanto, em junho de 2000, o Partido dos Trabalhadores (PT), ajuizou Ação Direta de Inconstitucionalidade (ADIn) $n^{\circ} 2.223$ junto ao Supremo Tribunal Federal (STF) contra a Lei Ordinária n 9.932/99.

A liminar concedida que suspendendeu os efeitos da mencionada lei, foi referendada pelo Plenário do STF, que entendeu ser necessária a edição de Lei Complementar para a regulamentação do artigo 192 da CF de 1988, e, portanto, para estabelecer a competência de fiscalização e regulamentação do setor de resseguros. Diante de tal decisão, foi paralisado o processo de leilão do IRB-Brasil Re e a abertura do mercado de resseguro.

\footnotetext{
${ }^{50}$ A redação do inciso II, do art. 192 passou a vigorar: "II. Autorização e funcionamento dos estabelecimentos de seguro, resseguro, previdência e capitalização, bem como do órgão fiscalizador".
} 
Com a aprovação da Emenda Constitucional n ${ }^{\circ}$ 40, em 29 de maio de 2003, permitindo a regulamentação do art. 192, coube a cada grupo de atividades do Sistema Financeiro Nacional ser regulamentado por Lei Complementar específica.

Em seqüência, deu-se a apresentação do Projeto de Lei Complementar $n^{\circ}$ 55/2003, em 12/06/2003, visando transferir as atribuições regulatórias e de fiscalização das operações de resseguro e retrocessão do IRB-Brasil Re para a SUSEP.

Em julho de 2004, no trâmite normal da Ação Direta de Inconstitucionalidade, o Procurador Geral da República e a Advocacia Geral da União proferiram pareceres no sentido de que as alterações no teor do art. 192 da CF, em função da Emenda 40/2003, teriam afastado a necessidade Lei Complementar, o que acarretaria a perda de objeto da referida ADIn. Aberto prazo para pronunciamento do PT, o partido não se manifestou, tendo sido os autos encaminhados ao Relator.

Desse modo, o IRB-Brasil Re continua a atuar, conforme disposições do Decreto-Lei $\mathrm{n}^{\circ}$ 73, de 21 de novembro de 1966, de forma monopolista e a manter seus poderes de regulamentação e fiscalização do co-seguro, do resseguro e da retrocessão, em face da indefinição da regulamentação da abertura do mercado brasileiro.

\subsection{O Quadro Atual}

A quebra do monopólio por ocorrer atenderá aos anseios dos mais diversos agentes.

Primeiramente, trata-se de um mercado de resseguro que movimentou mais de dois bilhões e oitocentos milhões de reais em prêmios anualmente, cerca de $7 \%$ dos prêmios de seguros, e que é pouco afetado por catástrofes naturais. ${ }^{51}$ Não podendo ser considerado, entretanto, em razão do monopólio, isolado do restante do

\footnotetext{
${ }^{51}$ Vide, nesse sentido,
} 
mercado internacional do resseguro. Principalmente, porque a dependência do Brasil do capital estrangeiro também se manifesta no resseguro.

Atualmente, mais da metade do total do resseguro do mercado brasileiro é feito no exterior e, dependendo do ramo, esta proporção se eleva até aos 95\%, como é o caso dos riscos aeronáuticos. ${ }^{52}$

O resseguro brasileiro está inserido no mercado de resseguros internacional, sofre suas pressões e interesses e é afetado pelas oscilações e instabilidades naturais desse mercado globalizado, o, a partir da catástrofe ocorrida em setembro de 2001, os preços das coberturas de retrocessão do IRB-Brasil aumentaram, tanto nos contratos automáticos como aqueles de cessão facultativa, na mesma proporção que haviam aumentado no mercado internacional de resseguro.

Por outro lado, verificou-se recentemente, fortes pressões das companhias resseguradoras internacionais junto aos seus governos, por ocasião das negociações entre Brasil e União Européia no intuito de aumentar a comercialização de produtos agrícolas. Os dirigentes europeus cobraram, em troca, a abertura do mercado de resseguros brasileiro.

Internamente, também observa-se uma "guerra" de interesses entre as principais companhias seguradoras. Há cinco anos, o grupo Bradesco vem comprando ações do IRB no mercado e hoje possui $42 \%$ das preferenciais e $22 \%$ do capital total. Por essa razão, nos últimos meses o Unibanco e Itaú se uniram a fím de exercer pressão junto ao Ministro da Fazenda para concluir o processo de privatização e quebra do monopólio do IRB e, dessa forma, enfraquecer a posição do Bradesco.

O interesse do Bradesco é que a privatização ocorra antes da quebra do monopólio para que possa vender suas ações a uma grande companhia resseguradora internacional. Caso ocorra inicialmente a quebra do monopólio essas ações perderiam o valor causando-lhe graves prejuízos.

\footnotetext{
${ }^{52}$ Vide, neste sentido, SCHWEIZER, Jean Paul.Um novo ciclo: para onde vai o resseguro no mundo e no Brasil? Cadernos de Seguros. N 128. janeiro de 2005. Rio de Janeiro: Funenseg. Pág 27-30.
} 
A redução do custo do resseguro e sua livre concorrência são os principais interesses das companhias seguradoras nacionais. Com a estabilidade econômica e depois com a abertura do Brasil para o mundo, o monopólio do IRB começou onerar o setor em função de uma série de limitações operacionais e taxas extras, que fazem com que o nosso resseguro chegue a custar até $20 \%$ a mais do que custam seus semelhantes no resto do mundo.

Além disso, a falta de competitividade decorrente do monopólio faz com que no país não tenha planos de resseguros tão sofisticados como os que estão à disposição das seguradoras instaladas em outros países, cujos produtos concorrem com os produtos brasileiros no mercado internacional. Como resultado tem-se o encarecimento dos produtos brasileiros, já que, não tendo planos de proteção modernos, as seguradoras necessitam assumir mais riscos, e, portanto, cobrar mais por cada apólice.

Há outro interesse das companhias seguradoras, peculiar do resseguro, que não está sendo plenamente atendido. Como já vimos, o resseguro não é só a transferência dos excedentes de responsabilidade ou de capacidade de retenção de uma companhia de seguros. Ao contratar uma empresa resseguradora ela procura proteção ou suporte para concorrer com empresas maiores, limitar seus riscos dentro de patamares pré-estabelecidos e tecnologia para emitir apólices para riscos dos quais ela não possui experiência para colocá-las no mercado. Em função do monopólio, as seguradoras nacionais praticamente só conseguem a transferência de seus excedentes, o que as deixa fora de alguns seguros comuns em outros países, como os de proteção para o agronegócio, ainda muito aquém do que acontece nos Estados Unidos e na Europa.

Por fim, continuam latentes os interesses de proteção nacionalistas que levaram o governo Vargas a criar o IRB, o qual durante décadas teve uma razão de ser importante e foi peça fundamental para a estruturar a atividade seguradora nacional, dando ao Brasil um mercado sólido, com empresas capitalizadas e aptas a fazerem frente às necessidades de proteção da sociedade. 
A título de exemplo, a declaração do ex-presidente do IRB-Brasil Re, Lídio Duarte, à revista Isto É Dinheiro, que por ser contra a privatização afirma “ $\mathrm{Se} o$ governo deixar uma empresa estrangeira comprá-lo, será como entregar a Embraer para a Bombardier". Esta é uma opinião sustentada por números que podem dar idéia do montante de divisas que permaneceram no país em face do monopólio. Só o ano passado, o IRB distribuiu US\$ 30 milhões às 23 corretoras credenciadas e teve um lucro líquido de $\mathrm{R} \$ 450$ milhões.

Do exame detalhado do mercado brasileiro de seguros e resseguros pode-se constatar que existe livre disputa entre as companhias de seguros, há liberdade de investimento de capital estrangeiro no mercado segurador, e só um fator restringe o grau de concorrência, a ausência de um verdadeiro mercado de resseguro à disposição do mercado de seguros brasileiro. $\mathrm{O}$ monopólio do resseguro aparenta ser, atualmente, algo estranho e forçado para um mercado aberto à forte concorrência. Afinal, Brasil e Cuba são os últimos países do mundo onde o resseguro é monopólio do Estado.

\subsection{O Novo Projeto de Lei Complementar}

Em 18 de maio recente, foi encaminhado pelo Poder Executivo ao Congresso Nacional, o Projeto de Lei complementar com vista a estabelecer a política de resseguros e retrocessão e respectiva intermediação, regulando, assim, parte do Sistema Financeiro Nacional, nos termos do art. 192 da Constituição Federal.

$\mathrm{O}$ projeto dispõe sobre operações de cosseguro, seguro no exterior e operações em moeda estrangeira do setor securitário, em função de atribuições hoje específicas do IRB-Brasil Resseguros S.A., conforme disposições do Decreto-Lei ${ }^{\circ}$ 73, de 21 de novembro de 1966. 
Cumpre abordar as proposições mais ligadas ao tema do trabalho em questão, deixando as avaliações dos assuntos ligados a operações em moeda estrangeira do setor securitário, embora atinentes ao IRB, para outra ocasião.

O projeto propõe a revogação da Lei 9.932, de 1999, que apesar de ter sido introduzida visando a transferência de atribuições de governo do IRB-Brasil Resseguros S.A. para a Superintendência de Seguros Privados - SUSEP, bem como a abertura desse mercado, sua implementação foi prejudicada, uma vez que pairam dúvidas quanto a sua constitucionalidade diante do art. 192 da Constituição Federal, que estabelece que a regulamentação do Sistema Financeiro Nacional seja feita por Leis Complementares.

O projeto ratificou a lei complementar $\mathrm{n}^{\circ} 109$, de 2001, que previu, em seu artigo 11, a possibilidade de contratação de operações de resseguro pelas companhias de previdência, através da inclusão dessas entidades como cedentes de risco em operações de resseguro (art. $\left.2^{\circ}, \S 1^{\underline{o}}, \mathrm{I}\right)$.

A proposição, além de atender a um dos princípios gerais e constitucionais da atividade econômica: a livre concorrência (art. 170, IV da CF), procura criar condições para o desenvolvimento do mercado de resseguros nacional, motivo pelo qual prevê oferta preferencial pelas seguradoras aos resseguradores que se instalarem localmente, sendo essa preferência de pelo menos 60\% nos dois primeiros anos após a regulamentação dos requisitos específicos para atuação de resseguradores (além do IRB-Brasil Re) no país e de 40\% nos anos subseqüentes. Essa preferência poderá ser ou não exercida pelos resseguradores locais, em face da natureza do risco envolvido e das estratégias das empresas, entre outros fatores (art. 11), mas observando-se a garantia de que a oferta dê-se em base equânime aos concorrentes internacionais (art. 11, § $2^{\mathrm{o}}$ ). A preferência poderá ser ajustada, por meio de lei ordinária, após o quarto ano, pressupondo-se que a partir deste prazo o mercado aberto já estará consolidado e as empresas a ele adaptadas (art. 11, $\S 1^{\mathrm{o}}$ ) motivo pelo qual o ajuste é limitado a $40 \%$ das cessões. 
O IRB-Brasil Resseguros S.A., neste contexto, é qualificado como ressegurador local (art. 22), sem solução de continuidade, concedendo-lhe a lei um prazo de 180 dias para a adaptação de suas operações de resseguro e retrocessão ao novo ordenamento jurídico (art. 22, parágrafo único). Neste ínterim, são mantidas as disposições legais referentes aos seus aspectos operacionais em vigor, revogando inicialmente apenas suas funções e dispositivos de natureza típica de Estado.

O modelo de abertura prevê não apenas a possibilidade de que haja mais competidores instalados no país, mas também que as cedentes nacionais (seguradoras, entidades de previdência complementar e resseguradores locais) possam realizar operações com resseguradores estrangeiros (art. $4^{\circ}$ ).

Considerando que as necessidades de transferência de risco às vezes demandam a pulverização em diversos resseguradores, especialmente nos casos de seguros vultosos, e considerando a possibilidade de haver resseguradores especializados que não tencionem atuar diretamente no país, foram propostas duas modalidades de resseguradores estrangeiros: o admitido e o eventual (art. $4^{\circ}$, II e III). O primeiro é aquele com efetivo interesse de atuação no mercado nacional, mas sem pretensão de se instalar como empresa local, e o segundo aquele que não dispõe de interesse em atuar localmente, podendo, entretanto, vir a fazê-lo em função do risco transferido. Para ambos, foram previstas exigências de cunho jurídico, econômico-financeiro e de qualificação (art. $6^{\underline{o}}$ ). Entretanto, a exigibilidade será maior para o ressegurador que opte por não se instalar de qualquer forma no país (ressegurador eventual), uma vez não estar sujeito à fiscalização direta, mas indireta via cedentes.

Visando caracterizar perfeitamente a falta de interesse no mercado local pelo ressegurador, foi proposta a existência de um limite de cessão para o ressegurador eventual pelas cedentes nacionais (art. $8^{\underline{o}}, \S 1^{\underline{o}}$ ).

Ao ressegurador admitido, foi concedida a abertura de conta em moeda estrangeira no país (art. $6^{\circ}$, parágrafo único, inciso I), favorecendo sua atuação e operacionalização financeira, ao mesmo tempo em que serão exigidas 
demonstrações financeiras de sua atuação (inciso II). Também foi introduzido a sujeição desse ressegurador à taxa de fiscalização prevista para o ressegurador local (art. $7^{\circ}$ ), dado que será ele, assim como o ressegurador local, fiscalizado pelos órgãos governamentais do país e para o qual também será possível ceder-se riscos não apenas de seguradoras, mas de entidades de previdência complementar.

Dessa forma, dada a natureza de mais longo prazo das operações de previdência complementar e de seguro de vida, restringiu-se o resseguro destes segmentos (art. 9oㅡㄹ parágrafo único) exclusivamente àqueles resseguradores dispostos a atuar efetivamente no país (locais e admitidos), considerando que os resseguradores eventuais não estão sujeitos à fiscalização direta dos órgãos governamentais locais.

Com essa medida que resguarda o consumidor, se agrega aquela que permite que o ressegurador ou retrocessionário pague diretamente ao segurado em caso de insolvência ou falência da empresa que cedeu os riscos, nos casos tecnicamente possíveis e previstos contratualmente (art. 14).

A proposta prevê o pagamento direto somente não tenha sido realizado pela entidade insolvente ao beneficiário, nem pelo ressegurador à cedente, uma vez que neste caso o ressegurador estaria pagando duas vezes e levando o ônus para toda a carteira de contratantes, pelo aumento de seu custo não estimado. Ressalvados os casos de cláusula de pagamento direto, prevê-se a manutenção das responsabilidades do ressegurador perante a massa liquidanda (art. 13) nas situações de insolvência das cedentes mesmo que estas não tenham realizado o pagamento dos sinistros, o que pode ter ocorrido, por exemplo, em função de sua própria solvabilidade.

As operações de transferência de risco poderão ser feitas tanto diretamente quanto através de corretor de resseguro (art. $8^{\circ}$ ), sendo este qualificado como corretor de seguros habilitado e especializado na atividade, e vinculado à corretora autorizada.

A proposta de lei complementar adiciona à abertura de mercado ao alinhamento com a legislação do mercado internacional quando transfere as 
atribuições reguladora e fiscalizadora do segmento para o órgão regulador e fiscalizador da atividade de seguros no país (art. $2^{\underline{0}}$ e $3^{\underline{0}}$ ) e quando propõe que o acervo do IRB-Brasil-Re seja fornecido ao novo órgão fiscalizador da atividade (art. $3^{\circ}$, parágrafo único), mediante cópia, permitindo o aproveitamento do histórico das informações do setor, na medida que a realidade assim impuser.

Propõe, também, que caberá ao CMN dispor sobre as operações de seguro, resseguro e retrocessão em moeda estrangeira (art. 18), observada a legislação em vigor, sendo que as especificidades de tais operações caberão ao órgão regulador da atividade de seguros. Ao CMN, ainda, caberá dispor sobre a abertura e manutenção de contas em moeda estrangeira, necessária para a operacionalização das operações nesta moeda.

Por fim, esta foi uma análise, sob a ótica do resseguro, do projeto de lei complementar que foi encaminhado à apreciação do Congresso Nacional, com a finalidade de estabelecer regulação do mercado de resseguros e das operações correlatas, realizadas no país e com o exterior. 


\section{Conclusão}

No curso do presente trabalho objetivou-se destacar a relevância da atividade resseguradora, a importância dos conhecimentos técnicos na formação e execução dos contratos de resseguros, os aspectos jurídicos e legislações que acompanharam sua evolução no âmbito nacional e, por fim, tecer algumas considerações acerca da perspectiva da abertura do mercado ressegurador.

Inicialmente, constatou-se que o resseguro tem por finalidade conferir estabilidade técnica e financeira às companhias seguradoras, decorrendo seu caráter internacional da aplicação, em amplo sentido, do princípio da mutualidade, ou seja, entre as seguradoras e resseguradoras, garantindo, assim, a pulverização dos riscos.

Em sua trajetória, pode-se observar que o resseguro acompanhou a evolução do desenvolvimento econômico, sofrendo sanções e se beneficiando de fatos históricos relevantes. Nesse ínterim, verifica-se o acerto da implantação do monopólio no país, por ocasião do Estado Novo, quando a atuação do IRB contribuiu de forma relevante para a consolidação do mercado segurador brasileiro.

Analisado no âmbito jurídico, possui o contrato de resseguro a natureza jurídica de um contrato de seguro de dano, intrinsecamente ligada ao conceito de risco. Em razão da escassez de normas para regulá-lo (no mundo) é a fonte primária das obrigações contratuais. Encontra-se regido, não só por seus princípios internacionais, como por aqueles que regem a atividade seguradora, em especial, o principio da mais estrita boa-fé. A estrita relação jurídica entre segurador e ressegurador, além de ser uma característica do resseguro desde o seu surgimento, é a própria essência da solvabilidade do sistema.

No Brasil, contrariamente a maioria dos países, pode se observar por questões econômicas e, por vezes, político-ideológicas, que nosso país sempre legislou e continua legislando sobre o resseguro, apesar de uma auto-regulamemtação internacionalmente conhecida. 
Atualmente, O IRB-Brasil Re padece da falta de uma definitiva delimitação de áreas de atuação e competência. Por razões que já não se justificam, mantém o anacronismo de acumular funções tipicamente de Estado e comportamento de empresa privada. O monopólio, que a primeira vista poderia parecer garantir ao mercado segurador brasileiro um grau de estabilidade nos preços e condições de resseguro, menos perceptível num sistema de resseguro aberto à concorrência, já não se comprova. Conceber o mercado ressegurador nacional como uma ilha equivale a negar os fatos e incorrer em sérios erros conceituais.

Um monopólio de resseguros é, efetivamente, um corpo estranho e limitador de um mercado de seguros aberto à forte concorrência como o brasileiro. Em um contexto cerradamente competitivo, cabe a companhia seguradora escolher o seu provedor de capacidade consoante suas necessidades e preferências, preços e condições, solidez financeira e qualidade de serviços oferecidos pelo ressegurador. Para o ressegurador, quanto melhor a qualidade e equilíbrio da carteira da cedente, menor será o preço da capacidade de resseguro, formando-se, dessa forma, um circulo virtuoso e sustentável.

Assim, a nova proposta de regulamentação para a tão aguardada abertura de mercado ressegurador, renova as perspectivas dos agentes brasileiros, com a possibilidade de entrada das grandes empresas mundiais do setor e, trazendo consigo, ao menos, duas grandes vantagens a médio prazo: o incremento tecnológico do mercado brasileiro de resseguro e as conseqüências lógicas da livre concorrência, isto é, melhores preços ou serviços, beneficiando não só as companhias seguradoras como, por via de conseqüência, os segurados. 


\section{Bibliografia}

ALVIM, Pedro. O contrato de seguro. $3^{\mathrm{a}}$ ed.. Rio de Janeiro: Forense, 1999. 547p. BARBOSA, Francisco Anthero Soares. A pulverização das responsabilidades: cosseguro, resseguro e retrocessão. Caderno de Seguros. Rio de Janeiro, v. 4, n.20, p.26-32, jan.fev. 1985.

BELLI, Valdemiro Cequinel. Seguro \& resseguro: internacionalização do mercado segurador brasileiro. Curitiba. 2002. 77 p. Monografia - Bacharelado em Ciências Econômicas da Universidade de Tuiuti do Paraná

BITTENCOURT, Marcelo Teixeira. Manual de Seguros Privados. Lumen Júris, 2004.

BOTTI, Paulo Eduardo de Freitas. Introdução ao resseguro: para brasileiros. São Paulo: Nobel, 1995. 155p.

CARNEIRO, Athos Gusmão et al. Seguros: uma questão atual. São Paulo: Editora Max Limonad, 2001. 409 p.

COSTA, José Octávio dos Santos. Resseguro no Brasil: retrospectiva e perspectiva. Seguros \& Riscos. São Paulo, v.6, n. 56, p. 43-45. 1999.

Resseguro no Brasil: retrospectiva e perspectiva. Seguros \& Riscos. São Paulo, v.6, n. 57, p. 52-54. 1999.

DI GROPELLO, Giulio. Princípios da Técnica de resseguro: resseguro financeiro e derivativos em resseguro. Colaboração de Giovanni Manguetti. Tradução e revisão de Maria Helena Bidino. Rio de Janeiro: Funenseg, 1997. 232 p.

DIRUBE, Ariel Fernandéz. Manual de Resseguros. São Paulo: General Cologne Re, 1992. $160 \mathrm{p}$.

ELLIOT, Michael W. et al.. Princípios de Resseguro. Tradução de Roberto Luiz Martins de Castro. Revisão de Maria Helena de Aguiar Huebra. v.1 e v. 2. Rio de Janeiro: Funenseg, 2001. 220 p. 
FAORO, André Leal. O monopólio do resseguro no Brasil. Revista de Direito da Procuradoria Geral da Susep. Rio de Janeiro, v.1, n.1, p. 107-110, jan./dez. 2002 FENASEG - FEDERAÇÃO NACIONAL DAS EMPRESAS DE SEGUROS PRIVADOS E DE CAPITALZAÇÃO. Estudos sobre a regulamentação do resseguro no Brasil. Rio de Janeiro: Fenaseg, 1998. 123 p.

Disponível em http:// www.fenaseg.org.br/

FIORI, Alexandre del. Diccionario de Seguros. São Paulo: Manuais Técnicos de Seguros, 1996.

GOMES, Orlando. Contratos. $18^{\mathrm{a}}$ ed. Rio de Janeiro: Forense, 1999. 523p.

GOTTHEIMER, George M.. Resseguro avançado. Tradução de Vera Casali R. Martins, revisão técnica de Antonio Salvador Dutra. $4^{\text {a }}$ ed. Rio de Janeiro: Funenseg, 1999. 250 p.

HADDAD, Marcelo Mansur. O resseguro internacional. São Paulo. 2002. 148 p.. Tese (Doutorado em Direito Internacional) - Faculdade de Direito da Universidade de São Paulo. Cadernos de Seguro: teses, v.8, n.16. Rio de Janeiro: FUNENSEG, 2003.

IRB-Brasil Resseguros S/A. Disponível em http:// www.brasil-re.com.br/ Acesso em: 01/06/2005.

MELLO, Sergio Ruy Barroso de.. Contrato de resseguro: aspectos normativos e conflitos jurídicos relevantes. Rio de Janeiro: Pellon \& Associados, 2000. 43 p.

Questões técnicas e jurídicas sobre coberturas em seguro e resseguro resultantes de 11 de setembro de 2001. Revista de Direito da Procuradoria Geral da Susep. Rio de Janeiro, v.1, n.1, p. 99-106, jan./dez. 2002.

Resseguro: reflexos jurídicos da evolução contratual. Revista do IRB. Rio de Janeiro, v.61, n. 284, p. 45-7, abr. /jun. 2001.

Ilegitimidade do segurado frente ao ressegurador e a garantia de risco. Revista do IRB. Rio de Janeiro, v. 61, n. 84, p. 37-40, jul. /set. 2001. 
MELlO FRANCO, Vera Helena. Lições de Direito Securitário. São Paulo: Maltese, 1993.

MENDONÇA, Antônio Penteado. A abertura do Resseguro. O Estado de São Paulo, São Paulo, Economia B7, 7 de mar. 2005.

Ainda sobre resseguro. O Estado de São Paulo, São Paulo, Economia B7, 14 de mar. 2005.

MESSINA, Adyr Pecego. Seguro e resseguro. Rio de Janeiro: IRB, York Indústria Gráfica, $1985.593 \mathrm{p}$.

MIRANDA, Pontes. Comentários ao Código de Processo Civil. $2^{\mathrm{a}}$ ed. Rio de Janeiro: Forense, 1979. Tomo II. p. 652

NASCENTES, Célio Olympio. A origem do seguro e do resseguro no mundo e sua implantação no Brasil. Revista IRB, v. 50, n. 250, p. 32-7, jul/set, 1989.

NERY JUNIOR, Nelson; NERY, Rosa Maria Andrade. Código de Processo Civil Comentado e legislação processual civil extravagante em vigor. $4^{\mathrm{a}} \mathrm{ed}$. rev. e ampl. São Paulo: Editora Revista dos Tribunais, 1999. 3007 p.

OLIVEIRA, Celso Marcelo de. Contrato de seguro: interpretação doutrinária e jurisprudencial. São Paulo: LZN, 2002. 794p.

PAGNOZZI, Flávia Reis. O seguro no Novo Código Civil e suas repercussões no contrato de resseguro. Revista do IRB. Rio de Janeiro, v.63, n.291, p. 29-31, jan./mar. 2003

PEREIRA, Caio Mário da Silva. Instituições do Direito Civil. $11^{\mathrm{a}}$ ed.. Rio de Janeiro: Editora Forense, 2003.

PFEIFFER, Christoph. Introdução ao Resseguro: $\mathrm{O}$ manual para teoria e prática. Tradução Ursula Gropp. 4ª ed. São Paulo: Editora Gabler, 1994.

PIMENTEL, Ayrton; TZIRULNIK, Ernesto; CAVALCANTI, Flávio Queiroz Bezerra. O contrato de seguro: novo Código Civil Brasileiro. São Paulo: IBDS/EMTS, 2002. 257p. 
PIZA, Paulo Luiz de Toledo. Tendências em matéria de resseguro - caso e ocaso brasileiro. Revista Brasileira de Direito de Seguros. São Paulo, v.3, n.9, p. 14-21, maio/ago. 2000.

Contrato de resseguro - tipologia, formação e direito internacional. São Paulo: IBDS, 2002. 531 p.

PÓVOAS, Manoel S. Soares. Direito do seguro. Rio de Janeiro: SBERJ, 1979. 5p. (SBERJ. Caderno especial, 201).

Na rota das Instituições de bem-estar: Seguro e Previdência. São Paulo, Editora Green Forest do Brasil, 2000. 436 p.

ROCHA, Janes. Presidente do IRB vê abertura gradual. Valor Econômico, São Paulo, C8, 24-27 mar. 2005.

SCHWEIZER, Jean Paul. Um novo ciclo: para onde vai o resseguro no mundo e no Brasil?. Caderno de Seguros. Rio de Janeiro, ano XXV, n. 128, Janeiro 2005.

SWISS REINSURANCE COMPANY. Introdução ao Resseguro. Zurique: Swiss Re, 1999. 34 p. 


\section{Glossário}

Balanço contábil: Relatório contábil que mostra as condições financeiras de uma companhia em uma data particular. Constam nesse relatório os ativos, as obrigações, o capital e os lucros da companhia.

Borderaux: Relatório fornecido periodicamente pelo ressegurado, detalhando os prêmios e/ou sinistros do resseguro com relação aos riscos específicos, cedidos através da operação de resseguro.

Capacidade: Cobertura máxima retentiva de uma seguradora, ressegurador ou, em sentido mais amplo, de determinado mercado de seguros. A capacidade de retenção dos seguradores é ampliada pela contratação de resseguro, tornando-se, dessa forma, o somatório da retenção própria dos mesmos, mais o limite de pretensão acordado com os resseguradores.

Capital segurado: Termo utilizado pelo resseguro para definir o valor do seguro no Seguro de Vida e Acidentes Pessoas.

Carteira: Denominação dada ao conjunto de contratos de seguros, de um mesmo ramo ou de ramos afins, emitidos por uma seguradora ou cobertos por um ressegurador.

Comissão de resseguro: Percentagem que o ressegurador paga ao segurador, pela cessão, total ou parcial, do seguro.

Desvio de sinistrabilidade: É a diferença, favorável ou desfavorável, na taxa de sinistrabilidade, em relação à taxa tecnicamente esperada, aferida a partir da taxa pura da carteira. 
Franquia: Termo utilizado pelo segurador para definir valor calculado matematicamente e estabelecido no contrato de seguro, até o qual ele não se responsabiliza a indenizar o segurado em caso de sinistro.

Fronting: Termo usado para indicar que o risco assumido por uma seguradora é ressegurado na sua globalidade, exceto nos casos em que as normas ou leis prevêem uma retenção mínima. Trata-se de um procedimento, particularmente, usado quando o ressegurador (nacional ou estrangeiro) não pode subscrever diretamente um determinado risco, mas, por vários motivos, tem interesse em assumi-lo na sua totalidade.

Importância Segurada: É o valor monetário atribuído ao patrimônio ou às conseqüências econômicas do risco sob a expectativa de prejuízos, para o qual o segurado deseja a cobertura de seguro, ou seja, é o limite de responsabilidade da seguradora, que nos seguros de coisas, não deverá ser superior ao valor do bem.

Indenização: É a contraprestação do segurador ao segurado que, com a efetivação do risco (ocorrência de evento previsto no contrato), venha a sofrer prejuízos de natureza econômica e faz jus à indenização pactuada.

Índice de sinistrabilidade (loss ratio): Corresponde ao percentual de prêmios que é utilizado para pagar sinistros.

Liquidação de sinistros: Expressão usada para indicar, nos seguros dos ramos elementares, o processo para apuração do dano havido em virtude da ocorrência do sinistro, suscetível de ser indenizado.

Natureza do risco: É a expressão usada para indicar a espécie ou qualidade do objeto segurado. 
Pro-rata: Diz-se do prêmio do seguro, calculado na base dos dias do contrato.

Provisões Téenicas: São assim chamadas algumas das reservas obrigatórias. Formam parte integrante e indispensável do mecanismo do seguro, são constituídas mensalmente e independem da existência de lucros nas seguradoras/resseguradoras. Em vista da natureza peculiar das várias modalidades operações da seguradoras, as Provisões Técnicas não são todas da mesma natureza, mas têm com objetivo a garantia da estabilidade econômico-financeira das seguradoras. Provisões Técnicas são também constituídas pelas Entidades de Previdência Privada, tanto Abertas quanto Fechadas e, também pelas Sociedades de Capitalização.

Pulverização do risco: Distribuição do seguro, por um grande número de seguradores, de modo a que o risco, assim disseminado, não venha a constituir, por maior que seja a sua importância, perigo eminente para a estabilidade da carteira.

Retenção: É a parte das responsabilidades pela qual o segurador ou o ressegurador o retroceder. A retenção também é designada, dependendo do contexto, se própria, global ou de mercado, por Limite, Pleno de Retenção (mais conhecido, simplesmente, por Pleno), Pleno Líquido, Pleno Bruto, Limite de Aceitação, Capacidade Retentiva e Capacidade de Aceitação.

Responsabilidade Civil Geral: Garante o reembolso de indenização que o segurado venha a ser obrigado a pagar em conseqüência de lesões corporais ou danos materiais, por ele provocados involuntariamente (por omissão, negligência ou imprudência) a terceiros ou a pessoas pelos quis possam responder civilmente. É o ramo de seguros que oferece maior variedades de cobertura.. 
Sinistralidade: Número de vezes que os sinistros ocorrem e seus valores. Mede a expectativa de perda, que é imprescindível para estabelecer o prêmio básico ou o custo puro de proteção.

Sinistro: Termo utilizado para definir em qualquer ramo ou carteira de seguro, o acontecimento do evento previsto e coberto no contrato.

SLIP: Documento com cláusulas, condições ou exclusões principais do contrato de resseguro, que a cedente ou o seu representante (broker) submete ao ressegurador na fase de colocação.

Subscritor (underwrite): Pessoa encarregada de subscrever riscos.

Subscrição de riscos: É a matéria pela qual os subscritores decidem quais os proponentes ao seguro que serão aceitos e quais serão rejeitados. Os subscritores decidem também a amplitude da cobertura que as seguradoras estão dispostas a conceder e o preço para concedê-las. Eles tentam proteger a seguradora da antiseleção de riscos (aumento da probabilidade de que os consumidores irão comprar seguro quando o prêmio é baixo em relação ao risco), bem com estudam todas as soluções razoáveis que possam estar disponíveis. 
ANEXo 


\section{PROJETO DE LEI COMPLEMENTAR}

Dispõe sobre a política de resseguro, cosseguro, retrocessão e sua intermediação, de seguro no exterior e as operações em moeda estrangeira do setor securitário, e dá outras providências.

O CONGRESSO NACIONAL decreta:

\section{CAPÍTULO I \\ DO OBJETO}

Art. $1^{0}$ Esta Lei Complementar dispõe sobre a política de resseguro, retrocessão e sua intermediação, bem como as operações de cosseguro, a contratação de seguro no exterior e as operações em moeda estrangeira do setor securitário.

\section{CAPÍTULO II \\ DA REGULAÇÃO E DA FISCALIZAÇÃO}

Art. $2^{\underline{0}}$ A regulação das operações de cosseguro, resseguro, retrocessão e sua intermediação será exercida pelo órgão regulador de seguros, conforme definido em lei, observadas as disposições desta Lei Complementar.

$\S 1^{\circ}$ Para fins desta Lei Complementar, considera-se:

I - cedente: sociedade seguradora ou entidade de previdência complementar que contrata operação de resseguro, ou ressegurador que contrata operação de retrocessão;

II - cosseguro: operação de seguro em que duas ou mais sociedades seguradoras, com anuência do segurado, distribuem entre si, percentualmente, os riscos de determinada apólice, sem solidariedade entre elas;

III - resseguro: operação de transferência de riscos assumidos por uma sociedade seguradora ou entidade de previdência complementar para um ressegurador; e resseguradores.

IV - retrocessão: operação de transferência de riscos de resseguro entre

$\S 2^{\underline{0}}$ A regulação pelo órgão de que trata o caput não prejudica a atuação dos órgãos reguladores das cedentes, no âmbito exclusivo de suas atribuições, em especial no que se refere ao controle das operações realizadas.

Art. $3^{0}$ A fiscalização das operações de cosseguro, resseguro, retrocessão e sua intermediação passará a ser exercida pelo órgão fiscalizador de seguros, conforme definido em lei, sem prejuízo das atribuições dos órgãos fiscalizadores das demais cedentes. 
Parágrafo único. O IRB-Brasil Resseguros S.A. fornecerá ao órgão fiscalizador da atividade de seguros cópia de seu acervo de dados, informações técnicas e de quaisquer outros documentos ou registros que este julgue necessários para o desempenho das funções de fiscalização das operações de seguro, cosseguro, resseguro e retrocessão.

\section{CAPÍTULO III \\ DOS RESSEGURADORES}

\section{Seção I \\ Da Qualificação}

Art. $4^{\circ}$ As operações de resseguro e retrocessão podem ser realizadas junto aos seguintes tipos de resseguradores:

I - ressegurador local: ressegurador com sede no País, constituído sob a forma de sociedade anônima, tendo por objeto exclusivo a realização de operações de resseguro e retrocessão;

II - ressegurador admitido: escritório de representação no País de ressegurador com sede no exterior que, atendendo às exigências previstas nesta Lei Complementar e nas normas aplicáveis à atividade de resseguro e retrocessão, tenha sido cadastrado no órgão fiscalizador de seguros, para realizar operações de resseguro e retrocessão; e

III - ressegurador eventual: ressegurador com sede no exterior que atenda aos parâmetros estabelecidos pelo órgão regulador de seguros para subscrever resseguro ou retrocessão de sociedades seguradoras e resseguradores locais.

\section{Seção II \\ Das Regras Aplicáveis}

Art. $5^{\circ}$ Aplicam-se aos resseguradores locais, observadas as peculiaridades técnicas, contratuais, operacionais e de risco da atividade e as disposições do órgão regulador de seguros:

I - as regras estabelecidas para as sociedades seguradoras; e

II - a legislação aplicável às sociedades seguradoras, inclusive as que se referem à intervenção e liquidação de empresas, mandato e responsabilidade de administradores e taxa de fiscalização.

Art. $6^{\circ} \mathrm{O}$ ressegurador estrangeiro, admitido ou eventual, deverá atender aos seguintes requisitos mínimos, sem prejuízo de outros que venham a ser fixados pelo órgão regulador de seguros:

I - estar constituído, segundo as leis de seu País de origem, para subscrever resseguros locais e internacionais nos ramos em que pretenda operar no Brasil e que tenha dado início a tais operações há mais de três e cinco anos, respectivamente; 
II - dispor de capacidade financeira não inferior à mínima estabelecida pelo órgão regulador de seguros;

III - ser portador de avaliação de solvência, por agência classificadora reconhecida pelo órgão fiscalizador de seguros, com classificação igual ou superior ao mínimo estabelecido pelo órgão regulador de seguros; e

IV - designar procurador com amplos poderes administrativos e judiciais, inclusive para receber citações judiciais, domiciliado no Brasil, para quem serão enviadas todas as notificações.

admitidos:

Parágrafo único. Constituem-se ainda requisitos para os resseguradores

I - manutenção de conta em moeda estrangeira, vinculada ao órgão fiscalizador de seguros, na forma e montante definido pelo órgão regulador de seguros para garantia de suas operações no País;

II - apresentação periódica de demonstrações financeiras, na forma definida pelo órgão regulador de seguros.

fiscalização.

Art. $7^{0}$ Aos resseguradores admitidos e locais aplica-se a mesma taxa de

\section{CAPÍTULO IV \\ DOS CRITÉRIOS BÁSICOS DE CESSÃO}

Art. $8^{\underline{0}}$ A contratação de resseguro e retrocessão no País ou no exterior será feita mediante negociação direta entre a cedente e o ressegurador ou por meio de intermediário legalmente autorizado.

$\S 1^{\mathrm{o}} \mathrm{O}$ limite máximo que poderá ser cedido anualmente a resseguradores eventuais será fixado pelo órgão regulador de seguros, podendo ser objeto de acordos internacionais.

$\S 2^{\mathrm{o}} \mathrm{O}$ intermediário de que trata o caput é o corretor de seguros especializado e habilitado vinculado à corretora de resseguro autorizada que disponha de contrato de seguro de responsabilidade civil profissional, na forma definida pelo órgão regulador de seguros.

Art. 9- A transferência de risco em operações de resseguro ou retrocessão somente pode ser realizada aos resseguradores locais, admitidos ou eventuais.

Parágrafo único. As operações de resseguro relativas a seguro de vida por sobrevivência e previdência complementar são exclusivas de sociedades resseguradoras locais e admitidas.

Art. 10. O órgão fiscalizador de seguros poderá ter acesso a todos os contratos de resseguro e de retrocessão, inclusive os celebrados no exterior, sob pena de ser 
desconsiderada, para todos os efeitos, a existência do contrato de resseguro e de retrocessão.

Art. 11. Observadas as normas do órgão regulador de seguros, as sociedades seguradoras deverão oferecer aos resseguradores locais, obrigatoriamente, preferência para o equivalente a pelo menos:

I - sessenta por cento de cessão de resseguro nos dois primeiros anos, contados da data da efetiva instalação no País de um mercado competitivo de resseguros; e

II - quarenta por cento de cessão de resseguro a partir de dois anos, contados da data da efetiva instalação no País de um mercado competitivo de resseguros.

$\S 1^{\underline{0}}$ Após quatro anos da data da efetiva instalação no País de um mercado competitivo de resseguros, o percentual de que trata o inciso II poderá ser alterado em lei, desde que respeitado o limite máximo de quarenta por cento.

$\S 2^{\underline{0}}$ As sociedades seguradoras somente poderão contratar resseguro no exterior quando os resseguradores locais não aceitarem o resseguro nas condições e preços obtidos junto a resseguradores estrangeiros mediante a prestação das mesmas informações transmitidas aos resseguradores locais, comprometidos, no conjunto desses resseguradores, a suportar, no mínimo, quarenta por cento do risco.

$\S 3^{0}$ Para fins do disposto nos incisos I e II do caput, considera-se efetiva instalação no País de um mercado competitivo de resseguros a vigência da regulamentação editada pelo órgão regulador de seguros dos requisitos exigidos para contratação junto a resseguradores locais, admitidos e eventuais.

\section{CAPÍTULO V \\ DAS OPERAÇÕES}

\section{Seção I \\ Das Disposições Gerais}

Art. 12. O órgão regulador de seguros estabelecerá as diretrizes para as operações de resseguro, retrocessão, corretagem de resseguro e escritório de representação do ressegurador admitido, observadas as disposições desta Lei Complementar. outras exigências:

Parágrafo único. O órgão regulador de seguros poderá estabelecer, entre

I - cláusulas obrigatórias de instrumentos contratuais relativos às operações de resseguro e retrocessão;

II - prazos para formalização contratual;

risco; e

III - restrições quanto à realização de determinadas operações de cessão de 

intra-grupo.

IV - requisitos para limites, acompanhamento e monitoramento de operações

Art. 13. Os contratos de resseguro deverão incluir cláusula dispondo que, em caso de liquidação da cedente, subsistem as responsabilidades do ressegurador perante a massa liquidanda, independentemente de os pagamentos de sinistros aos segurados, participantes, beneficiários ou assistidos haverem ou não sido realizados pela cedente, ressalvados os casos enquadrados no $\S 1^{\circ}$ do art. 14 .

Art. 14. Os resseguradores e os seus retrocessionários não responderão diretamente perante o segurado, participante ou beneficiário pelo montante assumido em resseguro e em retrocessão, ficando as cedentes que emitiram o contrato integralmente responsáveis por indenizá-los.

$\S 1^{\mathrm{o}}$ É permitida a inclusão de cláusula contratual de pagamento direto, quando tecnicamente possível, ao segurado, participante ou beneficiário, da parcela de indenização correspondente ao resseguro em caso de insolvência, de decretação de liquidação ou de falência da cedente, desde que o pagamento da respectiva parcela não tenha sido a ele realizado pela cedente contratada nem pelo ressegurador à cedente.

$\S 2^{\underline{o}}$ É vedado o pagamento da parcela ressegurada diretamente ao segurado, participante ou beneficiário quando não houver previsão contratual da cláusula de pagamento direto.

Art. 15. Nos contratos com a intermediação de corretoras de resseguro, não poderão ser incluídas cláusulas que limitem ou restrinjam a relação direta entre as cedentes e os resseguradores, nem se poderão conferir poderes ou faculdades a tais corretoras além daqueles necessários e próprios ao desempenho de suas atribuições como intermediário independente na contratação do resseguro.

Art. 16. Nos contratos a que se refere o art. 15, é obrigatória a inclusão de cláusula de intermediação, definindo se a corretora está ou não autorizada a receber os prêmios de resseguro, ou a coletar o valor correspondente às recuperações de sinistros.

Parágrafo único. Estando a corretora autorizada ao recebimento ou à coleta a que se refere o caput, os seguintes procedimentos serão observados:

I - o pagamento do prêmio à corretora libera a cedente de qualquer responsabilidade pelo pagamento efetuado; $\mathrm{e}$

II - o pagamento de sinistro à corretora só libera o ressegurador quando efetivamente recebido pela cedente.

Art. 17. A aplicação dos recursos das provisões técnicas e dos fundos dos resseguradores locais e dos recursos exigidos no País para garantia das obrigações dos resseguradores admitidos será efetuada de acordo com as diretrizes do Conselho Monetário Nacional - CMN. 


\section{Seção II \\ Das Operações em Moeda Estrangeira}

Art. 18. O seguro, o resseguro e a retrocessão poderão ser efetuados no País em moeda estrangeira, observadas a legislação que rege operações desta natureza, as regras fixadas pelo CMN e pelo órgão regulador de seguros.

Parágrafo único. O CMN disciplinará a abertura e manutenção de contas em moeda estrangeira, tituladas por sociedades seguradoras, resseguradores locais, resseguradores admitidos e corretoras de resseguro.

\section{Seção III \\ Do Seguro no País e no Exterior}

Art. 19. Serão exclusivamente celebrados no País os seguros obrigatórios e todos os seguros de caráter facultativo contratados por residentes, pessoas físicas, ou por pessoas jurídicas instaladas no território nacional, independentemente da forma jurídica, neste último caso para garantia de riscos no País.

Art. 20. A contratação de seguros no exterior é restrita às seguintes situações:

I - riscos com cobertura internacional, para os quais a vigência do seguro contratado se restrinja, exclusivamente, ao período em que o residente se encontra no exterior, desde que não haja oferta no País ou a contratação se dê durante a estada no exterior; e

II - riscos sem cobertura no País, desde que sua contratação não represente infração à legislação vigente.

Parágrafo único. Leis poderão dispor sobre seguros cuja contratação possa ser realizada no exterior, observado o interesse nacional.

\section{CAPÍTULO VI \\ DO REGIME DISCIPLINAR}

Art. 21. As cedentes, os resseguradores locais, os escritórios de representação de ressegurador admitido, os corretores e corretoras de seguro, resseguro e retrocessão, bem como quaisquer pessoas físicas ou jurídicas que descumpram as normas relativas à atividade de resseguro, retrocessão e corretagem de resseguros estão sujeitas às seguintes penalidades, aplicadas pelo órgão fiscalizador de seguros:

I - advertência;

II - multa pecuniária;

III - suspensão temporária do exercício da atividade;

IV - inabilitação, pelo prazo de dois a dez anos, para o exercício de cargo ou função em sociedades seguradoras, resseguradoras, de capitalização, entidades de 
previdência complementar, empresas e fundações públicas, sociedades de economia mista, autarquias e agências reguladoras; e

$\mathrm{V}$ - cancelamento de registro ou da autorização de funcionamento.

$\S 1^{0}$ A penalidade pecuniária será imputada ao agente responsável e à entidade em caráter solidário, conforme o caso, observadas as normas do órgão regulador de seguros, assegurado o direito de regresso.

$\S 2^{\mathrm{O}}$ A penalidade pecuniária será nos valores de $\mathrm{R} \$ 2.000,00$ (dois mil reais) a $\mathrm{R} \$ 1.000 .000,00$ (um milhão de reais), que serão periodicamente reajustados, a partir da publicação desta Lei Complementar, observadas as normas do órgão regulador de seguros e demais disposições legais pertinentes.

$\S 3^{0}$ A penalidade pecuniária poderá ser aplicada, cumulativamente, com as penalidades previstas nos incisos I, III ou V deste artigo.

$\S 4^{0}$ As infrações a que se refere o caput serão apuradas mediante processo administrativo regido conforme as normas estabelecidas para as sociedades seguradoras, sendo os recursos interpostos contra as decisões dos órgãos julgadores somente conhecidos, nos casos de multas pecuniárias, mediante seu depósito integral a favor do órgão fiscalizador de seguros.

\section{CAPÍTULO VII DAS DISPOSIÇÕES FINAIS}

Art. 22. O IRB-Brasil Resseguros S.A. fica autorizado a continuar exercendo suas atividades de resseguro sem qualquer solução de continuidade, independentemente de requerimento e autorização governamental, qualificando-se como ressegurador local.

Parágrafo único. O disposto nesta Lei Complementar passa a ser exigível, após cento e oitenta dias do início de sua vigência, às operações de resseguros e retrocessão realizadas pelo IRB-Brasil Resseguros S.A.

Art. 23. O sigilo de operações não poderá ser invocado como óbice à troca de informações entre o órgão fiscalizador de seguros, o Banco Central do Brasil, a Comissão de Valores Mobiliários, a Superintendência Nacional de Previdência Complementar - PREVIC e a Secretaria da Receita Federal, nem ao fornecimento de informações requisitadas pelo Ministério Público, aplicando-se às pessoas físicas e jurídicas de que trata esta Lei Complementar as disposições previstas na Lei Complementar $n^{\circ} 105$, de 10 de janeiro de 2001, e ao órgão fiscalizador de seguros, no âmbito de sua competência,

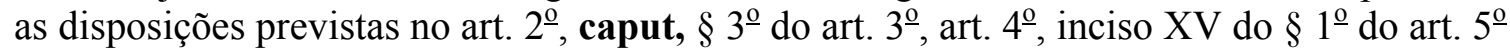
e nos arts. $7^{\circ}, 8^{\circ}$ e $9^{\circ}$ da citada Lei Complementar.

Art. 24. O caput do art. 111 do Decreto-Lei $n^{\circ}$ 73, de 21 de novembro de 1966, passa a vigorar com a seguinte redação: 
“Art. 111. Serão aplicadas multas no valor de R $\$ 2.000,00$ (dois mil reais) a R\$ 1.000.000,00 (um milhão de reais) às sociedades seguradoras e de capitalização que:" (NR)

Art. 25. Revogam-se os arts. $6^{-}, 15,45,58$ a 60,62 e 82 do Decreto-Lei $n^{\circ}$ 73, de 21 de novembro de 1966, a Lei no 9.932, de 20 de dezembro de 1999, e, a partir da edição da regulamentação de que trata o $\S 3^{\circ}$ do art. 11 desta Lei Complementar, o caput do art. 81, o parágrafo único do art. 100 e o art. 116 daquele Decreto-Lei.

Art. 26. Esta Lei Complementar entra em vigor na data de sua publicação.

Brasília,

EM № 00022/2005 - MF

Brasília, 09 de março de 2005.

Excelentíssimo Senhor Presidente da República,

Tenho a honra de submeter à elevada consideração de Vossa Excelência o anteprojeto de lei complementar que visa estabelecer a política de resseguros e retrocessão e respectiva intermediação, regulando assim parte do Sistema Financeiro Nacional, nos termos do art. 192 da Constituição Federal. Adicionalmente, este anteprojeto dispõe sobre operações de cosseguro, seguro no exterior e operações em moeda estrangeira do setor securitário, em função de atribuições hoje específicas do órgão ressegurador monopolista - IRB-Brasil Resseguros S.A., conforme disposições do Decreto-Lei $n^{0} 73$, de 21 de novembro de 1966.

2 .

O principal aspecto que esse anteprojeto visa disciplinar é a abertura do mercado de resseguros, uma vez que desde o advento da Emenda Constitucional $\mathrm{n}^{\mathrm{o}}$ 13, de 1997, o resseguro deixou de ser constitucionalmente monopólio do Estado. Apesar da Lei 9.932, de 1999, ter sido introduzida visando a transferência de atribuições de governo do IRB-Brasil Resseguros S.A. para a Superintendência de Seguros Privados, bem como a abertura desse mercado, sua implementação foi prejudicada, uma vez que pairam dúvidas quanto a sua constitucionalidade, diante do art. 192 da Constituição Federal, que estabelece que a regulamentação do Sistema Financeiro Nacional seja feita por Leis Complementares. Tais incertezas vêm prejudicando a concretização de investimentos que poderiam estar sendo realizados neste setor, motivo pelo qual propõe-se a sua revogação e a introdução do regramento geral da atividade através de lei complementar.

3. Além de novos investimentos, acreditamos que a abertura do mercado de resseguro contribuirá de forma significativa para o desenvolvimento do setor securitário local e, consequentemente, para o desenvolvimento econômico e social brasileiro. A possibilidade de instalação de novos resseguradores trará consigo elementos facilitadores para a ampliação da retenção nacional, o incremento da capacidade de subscrição das seguradoras e o aperfeiçoamento dos agentes econômicos envolvidos, ajudando, inclusive, 
a eliminar ineficiências hoje existentes que são importantes entraves ao desenvolvimento do mercado securitário nacional. A participação de novos agentes contribuirá para o aperfeiçoamento institucional, das seguradoras e dos próprios resseguradores locais, facilitando também a introdução de novos produtos. Todo esse movimento esperado levará à ampliação da demanda por especialistas no segmento, gerando novos postos de trabalhos que, dada a qualificação específica, levará à ampliação da demanda acadêmica, gerando um círculo virtuoso.

4. Os consumidores, provavelmente, serão os principais beneficiados, pelas perspectivas na maior oferta de produtos inovadores. Esta vantagem não se restringe ao setor de seguros propriamente dito, alcançando também o segmento de previdência complementar, na medida em que a lei complementar $\mathrm{n}^{\mathrm{o}}$ 109, de 2001, previu, em seu art. 11, a possibilidade de contratação de operações de resseguro pelas entidades de previdência, o que é ratificado neste projeto através da inclusão dessas entidades como cedentes de risco em operações de resseguro (art. $\left.2^{\underline{0}}, \S 1^{\underline{0}}, \mathrm{I}\right)$.

5. A proposição almeja, na verdade, atender a um dos princípios gerais e constitucionais da atividade econômica: a livre concorrência (art. 170, IV da CF). Contudo, preocupa-se também em criar condições para o desenvolvimento do mercado de resseguros nacional, motivo pelo qual prevê oferta preferencial pelas seguradoras aos resseguradores que se instalarem localmente, sendo essa preferência de pelo menos $60 \%$ nos dois primeiros anos após a regulamentação dos requisitos específicos para atuação de resseguradores (além do IRB-Brasil Re) no país e de $40 \%$ nos anos subseqüentes. Naturalmente, essa preferência poderá ser ou não exercida pelos resseguradores locais, em face da natureza do risco envolvido e das estratégias das empresas, entre outros fatores (art. 11), mas observando-se a garantia de que a oferta dê-se em base equânime aos concorrentes internacionais (art. 11, $\S 2^{\underline{o}}$ ).

6. A oferta estabelece um incentivo às empresas instaladas não apenas no momento inicial de captação de negócios, mas no período de estabilização de sua atividade empresarial, permitindo melhor planejamento e projeção de atuação em mais longo prazo. A preferência, no entanto, poderá ser ajustada, por meio de lei ordinária, após o quarto ano, pressupondo-se que a partir deste prazo o mercado aberto já estará consolidado e as empresas a ele adaptadas (art. $11, \S 1^{\underline{0}}$ ) - motivo pelo qual o ajuste é limitado a $40 \%$ das cessões.

7.

O órgão regulador disporá sobre a forma em que tal oferta ocorrerá, podendo realizar as adaptações que se façam necessárias no dia-a-dia do mercado, ao mesmo tempo em que regulará os demais aspectos da atividade do ressegurador local, em consonância com a legislação aplicável ao setor de seguros, mas observando-se as peculiaridades do resseguro (art. $5^{\circ}$ ).

$8 . \quad$ Dentro deste contexto, integra-se o IRB-Brasil Resseguros S.A. como ressegurador local (art. 22), sem solução de continuidade, concedendo-lhe a lei um prazo de 180 dias para a adaptação de suas operações de resseguro e retrocessão ao novo ordenamento jurídico (art. 22, parágrafo único). Neste ínterim, mantêm-se as disposições legais referentes aos seus aspectos operacionais em vigor, revogando-se inicialmente apenas suas funções e dispositivos de natureza típica de Estado.

9. Contudo, considerando-se o papel do IRB-Brasil Re hoje na instrumentação de políticas setoriais do governo, pretende-se a criação de um grupo de trabalho intra-governamental para avaliar em maior profundidade esse papel e delinear o grau de participação requerido para o governo neste segmento.

10. $\quad \mathrm{O}$ modelo de abertura prevê não apenas a possibilidade de que haja mais competidores instalados no país, mas também que as cedentes nacionais (seguradoras, entidades de previdência complementar e resseguradores locais) possam realizar operações com resseguradores estrangeiros (art. $4^{\circ}$ ). Trata-se de uma prática comum internacionalmente e mesmo atualmente no mercado nacional, e que já ocorre no modelo hoje em vigor, uma vez que o ressegurador IRB-Brasil Resseguros S.A., ao não dispor de capacidade para reter todos os riscos por ele subscritos, transfere para resseguradores 
estrangeiros uma parcela destes.

11

Considerando que as necessidades de transferência de risco às vezes demandam a pulverização em diversos resseguradores, especialmente nos casos de seguros vultosos, e considerando a possibilidade de haver resseguradores especializados que não tencionem atuar diretamente no país, são propostas duas modalidades de resseguradores

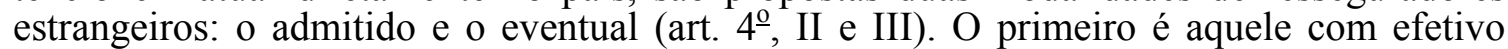
interesse de atuação no mercado nacional, mas sem pretensão de se instalar como empresa local, e o segundo aquele que não dispõe de interesse em atuar localmente, podendo, entretanto, vir a fazê-lo em função do risco transferido. Para ambos, são previstas exigências de cunho jurídico, econômico-financeiro e de qualificação (art. $6^{\circ}$ ), a serem detalhadas pelo ordenamento infralegal, propiciando, com isso, uma maior sintonia com a dinâmica das alterações da sociedade. Entretanto, a exigibilidade será maior para o ressegurador que opte por não se instalar de qualquer forma no país (ressegurador eventual), uma vez não estar sujeito à fiscalização direta, mas indireta via cedentes.

12

Ao mesmo tempo, visando caracterizar perfeitamente a falta de interesse no mercado local, propõe-se a existência de um limite de cessão para o ressegurador eventual pelas cedentes nacionais (art. $\left.8^{\circ}, \S 1^{\circ}\right)$. Ao ressegurador admitido, possibilita-se a abertura de conta em moeda estrangeira no país (art. $6^{0}$, parágrafo único, inciso I), favorecendo sua atuação e operacionalização financeira, ao mesmo tempo em que se exige demonstrações financeiras de sua atuação (inciso II). Também se introduz a sujeição desse ressegurador à taxa de fiscalização prevista para o ressegurador local (art. $7^{-0}$ ), dado que será ele, assim como o ressegurador local, fiscalizado pelos órgãos governamentais do país e para o qual também será possível ceder-se riscos não apenas de seguradoras, mas de entidades de previdência complementar.

13

Deste modo, considerando que os resseguradores eventuais não estão sujeitos à fiscalização direta dos órgãos governamentais locais e dada a natureza de mais longo prazo das operações de previdência complementar e de seguro de vida por sobrevivência, restringe-se o resseguro destes segmentos (art. 9oㅡㅁ, parágrafo único) exclusivamente àqueles resseguradores dispostos a atuar efetivamente no país (locais e admitidos).

14. Trata-se de medida que resguarda o consumidor, à qual se agrega aquela que permite que o ressegurador ou retrocessionário pague diretamente ao segurado em caso de insolvência ou falência da empresa que cédeu os riscos, nos casos tecnicamente possíveis e previstos contratualmente (art. 14). É medida de relevo, especialmente minimizando o risco dos segurados de riscos vultosos, que têm contratos de resseguro firmados especificamente para cobertura de seus riscos e para os quais é elevada a cessão de resseguro. Nesses casos, há uma vinculação direta entre a operação de seguro e a de resseguro, nem sempre existente, uma vez que o resseguro cobre a seguradora ou entidade de previdência complementar e não o segurado/participante. $\mathrm{O}$ pagamento direto, entretanto, somente poderá ocorrer caso não tenha sido realizado pela entidade insolvente ao beneficiário, nem pelo ressegurador à cedente, uma vez que neste caso o ressegurador estaria pagando duas vezes e levando o ônus para toda a carteira de contratantes, pelo aumento de seu custo não estimado. Ressalvados os casos de cláusula de pagamento direto, prevê-se a manutenção das responsabilidades do ressegurador perante a massa liquidanda (art. 13) nas situações de insolvência das cedentes mesmo que estas não tenham realizado o pagamento dos sinistros, o que pode ter ocorrido, por exemplo, em função de sua própria solvabilidade.

15 .

As operações de transferência de risco poderão ser feitas tanto diretamente quanto através de corretor de resseguro (art. $8^{\circ}$ ), sendo este qualificado como corretor de seguros habilitado e especializado na atividade, e vinculado à corretora autorizada. Considerando a responsabilidade existente na colocação de riscos e seus efeitos relacionados, busca-se introduzir no ordenamento jurídico nacional o seguro de responsabilidade profissional deste intermediário, visando a proteção das entidades cedentes de riscos contra seus erros e omissões. Cláusulas contratuais, prazos para 
formalização contratual, restrições quanto a realização de determinadas operações de cessão de risco e requisitos para operações intra-grupo são algumas das variáveis relevantes a serem consideradas pelo órgão regulador (art. 12, parágrafo único).

16 .

No que tange às corretoras de resseguro e sua relação contratual com as cedentes e resseguradores, são previstos alguns salvaguardas, além do seguro, àqueles que têm suas operações por elas intermediadas. Em primeiro lugar, a atuação da corretora não pode limitar ou restringir a relação direta entre as partes que intermedeie (art. 15). Em segundo lugar, a transparência da responsabilidade quanto à tramitação financeira através da corretora deve ser caracterizada contratualmente, de modo a inibir práticas inadequadas (art. 16, caput). Em terceiro lugar, resguarda-se, em última instância, o segurado ou participante da atuação intermediadora da corretora, uma vez que a entrega do prêmio à corretora implica a cobertura nos termos contratuais e a recuperação de sinistro a ela tramitado não libera o ressegurador, somente ocorrendo quando concluída a operação regra que demanda um melhor monitoramento deste da atuação da corretora, melhor seletividade e maior profissionalização (art. 16, parágrafo único), justificável em face dos volumes financeiros envolvidos.

17. Adicionalmente ao modelo de abertura, transfere-se as atribuições reguladora e fiscalizadora do segmento para o órgão regulador e fiscalizador da atividade de seguros no país conforme definido em lei (art. $2^{\underline{0}}$ e $\left.3^{\underline{0}}\right)$, convergindo nossa legislação à do mercado internacional. Tendo em vista o acervo que o IRB-Brasil Resseguros S.A, como monopolista, regulador e fiscalizador da atividade no país, acumulou ao longo de seus mais de 60 anos de atuação, propõe-se que tal acervo seja fornecido ao novo órgão fiscalizador da atividade (art. 3 $3^{\underline{0}}$, parágrafo único), mediante cópia, permitindo o aproveitamento do histórico das informações do setor, na medida que a realidade assim impuser. O IRB-Brasil Re, neste contexto, perde suas funções de órgão regulador e fiscalizador do cosseguro, resseguro e retrocessão, bem como de colocações no exterior para o mercado.

18

Por outro lado, os ativos garantidores das provisões técnicas, bem como os recursos exigíveis no país para os resseguradores ficam subordinados à regulação do Conselho Monetário Nacional - CMN (art. 17), como ocorre com todas as cedentes seguradoras e entidades de previdência complementar. Também caberá ao CMN dispor sobre as operações de seguro, resseguro e retrocessão em moeda estrangeira (art. 18), observada a legislação em vigor, sendo que as especificidades de tais operações caberão ao órgão regulador da atividade de seguros. $\mathrm{O}$ dispositivo se enquadra dentro da competência do CMN, conforme definida no inciso $\mathrm{V}$ do art. $4^{\underline{0}}$ da Lei $\mathrm{n}^{\mathrm{o}} 4.595$, de 31 de dezembro de 1964, alterado pelo Decreto-Lei $\mathrm{n}^{\mathrm{O}}$ 581, de 14 de maio de 1969 , voltado no presente caso ao setor securitário. Ao $\mathrm{CMN}$, ainda, caberá dispor sobre a abertura e manutenção de contas em moeda estrangeira, necessária para a operacionalização das operações nesta moeda.

19. Conjugado às questões em moeda estrangeira, o projeto trata do seguro no exterior (art. 19 e 20), atualmente disposto pelo art. $6^{0}$ do Decreto-Lei $n^{0} 73$, de 1966 , que prevê sua realização exclusivamente em casos em que não haja cobertura no país ou que não convenham aos interesses nacionais. A tramitação das exceções de contratação no país era realizada através do IRB-Brasil Resseguros S.A. que não deterá mais as funções de governo de controle destas operações. A nova redação dada ao citado artigo, para o qual se propõe revogação, visa tornar mais clara e transparente ao público em geral as situações em que a exigibilidade de contratação incide no país, bem como introduz-se a faculdade de leis ordinárias disporem sobre excepcionalidades, como ocorre, por exemplo, no art. 11 da Lei n⿳0 9.432, de 1997, no limite nela estabelecido, para os seguros de embarcações registradas no Registro Especial Brasileiro - REB.

20. No âmbito do resseguro e suas operações correlatas, por outro lado, introduz-se o regime sancionatório (art. 21), por descumprimento à lei que ora se propõe e também à sua regulamentação infralegal, aplicável pelo órgão fiscalizador de seguros, especificando-se a exigibilidade de depósito de multa por força do $\S 2^{-}$do art. 56 da Lei $\mathrm{n}^{\mathrm{o}}$ 9.784, de 29 de janeiro de 1999, uma vez que sua inexistência pode induzir à entrada de 
recursos como veículo de postergação para o respectivo pagamento, situação não salutar para o sistema. Adicionalmente, elevam-se (art. 24) os montantes das multas aplicáveis às sociedades seguradoras e de capitalização, igualando-os àqueles incidentes às entidades de previdência complementar, conforme lei complementar $\mathrm{n}^{\mathrm{o}} 109$, de 2001, e aos ora propostos para as operações relacionadas a resseguro e retrocessão.

21. Introduz-se dispositivo que possibilita a troca de informações entre os órgãos que fiscalizam o setor (art. 23), objetivando-se maior eficiência de sua atuação perante as pessoas físicas e jurídicas de que trata a lei proposta, estendendo-se ao órgão fiscalizador de seguros, no âmbito de suas responsabilidades, as disposições aplicáveis à Comissão de Valores Mobiliários previstas na Lei Complementar $\mathrm{n}^{\mathrm{o}}$ 105, de 10 de janeiro de 2001, para cujo setor também a referida lei se aplica. Deste modo, as entidades fiscalizadas estão sujeitas a sigilo em suas operações e ao órgão fiscalizador é dada a amplitude fiscalizatória necessária para melhor aferir a realidade das operações realizadas e das movimentações financeiras correspondentes, podendo inclusive firmar convênios com outros órgãos internacionais que favoreçam à sua melhor atuação.

22. Tal função assume especial relevância diante da abertura do mercado de resseguros, devido às operações que envolvem riscos vultosos, em certa medida realizadas com o mercado internacional, algumas das vezes sem a supervisão direta do órgão fiscalizador local. Dentro deste contexto e diante de situações de risco, como insolvência, que podem vir a afetar as empresas cedentes de riscos, o órgão fiscalizador de seguros poderá solicitar à autoridade competente, mediante a instauração de inquérito administrativo, o levantamento do sigilo de informações relativas a bens, direitos e obrigações das instituições por ele supervisionadas, propiciando sua ação mais ágil na solução dos problemas e nos efeitos correlatos. São medidas possibilitadas pela Lei Complementar $\mathrm{n}^{\mathrm{o}} 105$.

23 .

Enfim, é o projeto de lei complementar que ora submetemos à superior consideração, com a finalidade de estabelecer o marco regulatório geral do mercado de resseguros e regular operações correlatas, realizadas no país e com o exterior, revogando dispositivos legais afetos à matéria.

Respeitosamente, 